\title{
Climate change in the Congo Basin: processes related to wetting in the December-February dry season
}

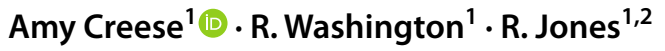 \\ Received: 15 October 2018 / Accepted: 11 March 2019 / Published online: 6 April 2019 \\ (C) The Author(s) 2019
}

\begin{abstract}
The Congo Basin is one of three key areas of tropical convection and contains the planet's second largest rainforest. Understanding how global warming might change its climate is crucial, particularly during the dry seasons, when rainfall amounts currently bring the rainforest boundaries close to the threshold of viability. There is considerable uncertainty in projections of future rainfall change from the Coupled Model Intercomparison Project (CMIP5) under the high-emissions experiment (RCP8.5). Whilst there is a general trend towards wetting in most months, its magnitude varies considerably. In the December to February dry season, the projected change in seasonal rainfall varies from 2 to $160 \mathrm{~mm}$ across models. This study uses a regionally-focused process-based assessment to understand inter-model differences in rainfall projections, as a first step to assessing their plausibility. Models which produce the most wetting by the end of the century feature enhanced convection over the Congo Basin region, enhanced subsidence in the African subtropics, and decreased uplift over the Maritime Continent. In contrast, models with a small wetting response feature reduced convection over the Congo Basin. This indicates that wetting over the Congo Basin is related to a weakening of the Indian Ocean Walker circulation, reminiscent of a positive Indian Ocean Dipole state. Models with the highest magnitude wetting also feature greater low-to-mid-level moisture flux from the north and the east compared to models with less wetting. These results indicate that the future degree of wetting over the Congo Basin will be linked to changes in convection over the Maritime Continent.
\end{abstract}

Keywords Congo Basin $\cdot$ CMIP5 $\cdot$ Rainfall $\cdot$ Climate change $\cdot$ Climate model evaluation

\section{Introduction}

The Congo Basin hosts the planet's second largest rainforest, a vital global carbon store and significant element of the global carbon cycle. However, changes in regional precipitation under climate change have the potential to influence rainforest composition and distribution (Malhi and Wright 2004). The Congo rainforest already exists close to the hydrological limits which support a closed-canopy

Electronic supplementary material The online version of this article (https://doi.org/10.1007/s00382-019-04728-x) contains supplementary material, which is available to authorized users.

Amy Creese

amy.creese@ouce.ox.ac.uk

1 School of Geography and the Environment, University of Oxford, Oxford OX1 3QY, UK

2 Met Office Hadley Centre, FitzRoy Road, Exeter EX1 3PB, UK forest, particularly at the boundaries, and there is evidence of rainforest contraction and changes to forest composition during drier periods in the past 3000 years (Brncic et al. 2007; Ngomanda et al. 2007; Lewis et al. 2009; Malhi et al. 2013). It is therefore crucial that possible climatic changes in the region are understood, in order to provide decisionmakers with the most credible information for mitigation and adaptation planning.

However, despite its climatic importance, the Congo Basin is critically understudied, particularly in terms of the likely effects of anthropogenic climate change. A lack of homogenous and widespread rainfall records has meant traditional methods of model evaluation are limited, and the lack of data with which to test models is likely to have contributed to extreme model divergence in this region (Washington et al. 2013). As models are our only tool for diagnosing and assessing future climate change, this has contributed to considerable uncertainty in the likely changes in this region. Recent work analysing models in the Coupled Model Intercomparison Project (CMIP5) over the 
Congo Basin has found that coupled global climate models (GCMs) can differ in their climatological mean rainfall by up to a factor of five in some months, with the largest differences found in December, when the equatorial and northern parts of the basin experience a dry season (Creese and Washington 2016). Recent efforts have concentrated on understanding model uncertainties in the basin's wet seasons of March-May (MAM) and September-November (SON) (James et al. 2013; Washington et al. 2013; Creese and Washington 2016, 2018), whereas the dry seasons have been largely overlooked. However the effects of climate change on the rainforests are likely to be felt most keenly during the dry seasons, when rainforest boundaries in the north and south of the region already exist close to the rainforest-savannah rainfall threshold (Malhi et al. 2013). A shift in the location or intensity of rainfall in the dry seasons in the future is likely to have implications for the rainforest extent, which in turn is likely to influence the carbon storage capacities of the region (James et al. 2013; Malhi et al. 2013). These changes are also likely to occur concurrently with increasing rates of deforestation in the region, which some studies have found to result in drier and warmer conditions in parts of the Congo Basin, by affecting evapotranspiration, cloud physics and moisture circulation patterns (Maynard and Royer 2004; Werth and Avissar 2005; Bala et al. 2007; Akkermans et al. 2014; Bell et al. 2015).

This paper aims to help address these knowledge gaps by conducting an assessment of the plausibility of signals of rainfall change in the broad Congo Basin region $\left(8^{\circ} \mathrm{E}-35^{\circ} \mathrm{E}\right.$, $10^{\circ} \mathrm{S}-10^{\circ} \mathrm{N}$ ), focusing particularly on the December to February (DJF) dry season. Where previous work has focused on determining the credibility of models in the historical period (Creese and Washington 2016, 2018), this paper will add to these insights by examining processes which are related to model simulations of future rainfall change. This approach will be a vital first step towards providing reliable projections of future change in the region.

\subsection{Congo Basin rainfall change}

There have been few attempts to understand the mechanisms of rainfall change and uncertainties in the range of future projections across models in the Congo Basin. Studies have thus far focused on rainfall changes in the region simulated in large model ensembles. Haensler et al. (2013) analysed changes in rainfall across 77 climate change projections, including models from the CMIP3, CMIP5 and CORDEX projects. They found that the multi-model mean (MMM) does not indicate severe rainfall changes across the region by the end of the century, even under the highest emissions scenarios. Across the whole multi-model ensemble (MME), they find a large range of mean simulated rainfall change; in one region during DJF, the range spans from $-50 \%$ to
$+150 \%$. Using a skill scores-based approach to choose a subset of models based on their realism in representing the historical rainfall climatology compared to observations, Aloysius et al. (2016) find that large heterogeneities also exist in spatial patterns of annual mean rainfall change in CMIP5, contributing to overall uncertainty in projections for this region. This model subset projects slightly higher magnitude rainfall change than in the full MME, and features a smaller range in the signal.

James et al. (2013) analysed the rainfall projections over the Congo Basin in the CMIP3 ensemble and two Hadley Centre perturbed physics ensembles (PPEs), finding substantial variation amongst models. However, some patterns emerged; the majority of models featured some wetting in the east of the domain and drying in the west of the domain during the September-November rainy season. An analysis of the dynamics associated with this change indicated shifts in the zonal circulation may be related to rainfall changes, and this understanding could be used in further work to assess the plausibility of such changes.

There has also been some work on rainfall projections from regional models (RCMs). Pokam et al. (2018) analysed the rainfall changes in the region at $1.5^{\circ} \mathrm{C}$ and $2{ }^{\circ} \mathrm{C}$ of warming in the Coordinated Regional Climate Downscaling Experiment (CORDEX) models. They found that in the parent GCMs, there is a tendency for wetting across the basin in the future, whereas in the RCMs there is uncertainty in the sign of change across models, with roughly half of models projecting mean negative changes and half mean projecting positive changes. This is the case at both temperature thresholds, as well as across different forcing pathways (Representative Concentration Pathways; RCPs). There is also disagreement amongst models as to the spatial pattern of rainfall change across the basin in some seasons. Saeed et al. (2013) compare rainfall projections in the regional climate model REMO to its driving GCM MPI-ESM, finding that the former projects rainfall decreases while the latter projects rainfall increases. By assessing the land surface processes associated with rainfall, they find that the RCM's tendency to simulate more extreme rainfall events led to higher surface runoff and less soil moisture, resulting in a less intense hydrological cycle and lower rainfall overall. Given that the number of extreme events in the RCM better matches the observational data, they suggest the RCM's projection may be more reliable than the GCM.

\subsection{Mechanisms of tropical rainfall change under warming}

The processes relating to model rainfall change in the Congo Basin will be embedded within larger structures of change in tropical rainfall. The response of tropical rainfall to warming is complex, and involves several interlinked and sometimes 
opposing mechanisms of change. The increase in atmospheric moisture content $(q)$ under warming may result in enhanced moisture transport, and thus enhanced moisture convergence (divergence) in regions which are already feature convergence (divergence) (Chou and Neelin 2004; Held and Soden 2006). This 'wet-gets-wetter' mechanism and has been found to occur in model simulations at very large spatial scales, as well as in recent observational data (Allan et al. 2010; Allan 2012; Durack et al. 2012). To some extent the wet-gets-wetter response will be opposed by the dynamical weakening of the tropical overturning circulation, resulting from the differential rate of increase in $q$ and rainfall (Allen and Ingram 2002; Held and Soden 2006; Vecchi and Soden 2007; Ma et al. 2012; Chadwick et al. 2013). This weakening of the circulation has been found to occur more robustly zonally, in the Walker cell, than meridionally, in the Hadley cell (Vecchi and Soden 2007).

Other dynamical mechanisms of rainfall change include: the 'warmer-gets-wetter' mechanism (Xie et al. 2010), whereby the spatial pattern of sea-surface temperature (SST) change is important in inducing changes in convection over oceans; changes in atmospheric circulation (Shepherd 2014); land-sea temperature contrasts (Dong et al. 2009); and the direct and indirect effects of aerosols (Hansen et al. 1997; Lohmann and Feichter 2004; Huang et al. 2007). Recent studies have also identified connections between dynamical and thermodynamical mechanisms; Huang et al. (2013) find that annual mean rainfall in the tropics is dominated by the warm-gets-wetter response near the equator, while seasonal anomalies of rainfall change follow the wet-getswetter response.

The warm-gets-wetter and wet-gets-wetter mechanisms are useful for explaining patterns of change over large spatial scales and across oceans. However there are still uncertainties regarding the balance of these mechanisms at regional scales and over land (Chadwick et al. 2013), reflected in the fact that at a regional-scale there is much less agreement amongst models in the patterns and behaviours of rainfall change (e.g. Meehl et al. 2007; Rowell 2012). In their assessment of spatial changes in tropical precipitation, Chadwick et al. (2013) showed that when rainfall change in CMIP5 models is decomposed into its constituent parts, the spatial patterns of the wet-gets-wetter component and the dynamically-driven weakened large-scale circulation component largely cancel one another out, leaving the pattern of rainfall change to be dominated by other, regional dynamical mechanisms, primarily relating to shifts in the location of convection. Similar results have been found over Africa. Lazenby et al. (2018) note that model uncertainty over southern Africa and the south west Indian Ocean is related most strongly to shifts in the location of convection, associated with SST-gradients over the Indian Ocean. Giannini et al. (2018) use a different decomposition metric to understand the contribution of thermodynamic and dynamic mechanisms to rainfall change in East Africa during the wet seasons, finding that the wetting signal in the CMIP5 multi-model mean (MMM) can be explained by circulation changes including the advection of moisture away from the Congo Basin to the East African margin. Rowell and Chadwick (2018) also find that uncertainties in the East Africa response to warming primarily derive from uncertainties in regional dynamics across the CMIP5 ensemble, related to spatial shifts in convection due to SST warming.

Dynamical mechanisms are also likely to be a particularly important consideration for understanding model diversity in the Congo Basin. Rainfall in the region is governed not only by the north-south movement of the tropical rain band, but also a complex set of regional factors, including topography, mid-level jets, local overturning cells, monsoon winds, landsea interactions, and mesoscale convective systems (e.g. Nicholson and Grist 2003; Balas et al. 2007; Jackson et al. 2009; Pokam et al. 2012; Cook and Vizy 2015; Dezfuli et al. 2015; Dezfuli 2017; Nicholson 2017). All of these processes will exhibit responses to GHG-induced warming, which will complicate the large-scale picture of tropical rainfall change in this region.

\subsection{A process-based assessment of change}

The studies described above give useful insights into the range of projections in this region, and the possible tropicswide mechanisms that may cause them. A regionally-focused process-based investigation will help further determine the plausibility of model projections via an examination of the processes behind such changes. Such assessments examine the processes associated with rainfall in models, with the aim of determining the credibility of the simulated rainfall, either in the historical or future periods. For example, James et al. (2015) determined the processes associated with drying in historically dry years in the Sahel from reanalysis data, and found them to differ from the processes causing dry years simulated in the current climate of a model ensemble. On finding that the same spurious processes were responsible for the drying in the future, they concluded that we could not trust projections of extreme drying in this region in the sample of models analysed. In the Congo Basin, Creese and Washington (2018) identified a chain of processes leading to extremely wet or dry mean climatologies during the SON wet season in CMIP5 models. They found that models with extremely wet western subdomains also featured larger and more persistent Atlantic SST biases, casting doubt on the credibility of those models' climatologies.

Process-based assessments can help to overcome some of the issues of using large ensembles of models. While MMMs are sometimes found to give the 'best estimate' of climates, with the suggestion that the averaging process cancels out 
errors in individual models and highlight similarities (Hagedorn et al. 2005; Palmer et al. 2005; Reichler and Kim 2008), there is reason to be cautious about their use in the Congo Basin. Previous analysis indicates that in the Congo Basin, large model disparities in both rainfall magnitude and distribution result in MMMs that are not representative of any individual models (Creese and Washington 2016); there are also many inter-related models in inter-comparison projects such as CMIP, which can skew the MMM. In addition, the scarcity of observational data in the region, and non-trivial differences between observational products, limits somewhat the strength of approaches based on skill in replicating historical climatology (Washington et al. 2013; Creese and Washington 2016). As Aloysius et al. (2016) highlight, an analysis of how well models represent causal mechanisms of change is also required to determine model plausibility, and the authors highlight some mechanisms which may be of particular importance (e.g., SST departures, sources and fluxes of atmospheric moisture). This paper will thus undertake a more in-depth analysis of such processes involved in rainfall change across individual models.

\subsection{Aims}

In light of the uncertainties in both historical and future rainfall climatologies in this region, the focus of this study is to explain the spectrum of model projections of rainfall. We hypothesize that both the low-level and overturning circulations will help to differentiate between modelled rainfall changes, given their importance in describing both interannual variability in observations, and inter-model differences in rainfall (e.g. Pokam et al. 2012, 2014; Cook and Vizy 2015; Creese and Washington 2016, 2018). Understanding such processes will be an important starting point for future work investigating the plausibility of projected changes.

Specifically, this study aims to:

1. Quantify and characterise the spectrum of rainfall changes in the Congo Basin between the end of the twentieth and end of twenty-first century across CMIP5 models. The focus will be the season with the strongest rainfall change signal, DJF.

2. Identify the large-scale circulation changes associated with the inter-model spread in projections of rainfall change in DJF.

3. Assess different model rainfall projections in the Congo Basin in the context of proposed mechanisms of tropicswide rainfall change.

\section{Data and methods}

This study uses two domains for its assessment of the Congo Basin; the first, used in Sect. 3 , is $8^{\circ} \mathrm{E}-35^{\circ} \mathrm{E}$, $10^{\circ} \mathrm{S}-10^{\circ} \mathrm{N}$ (red box, Fig. 4), following Creese and Washington (2018). From Sect. 4 (Fig. 3) onwards, the smaller domain $10^{\circ} \mathrm{E}-35^{\circ} \mathrm{E}, 10^{\circ} \mathrm{S}-5^{\circ} \mathrm{N}$ is used (green box, Fig. 4), to reflect the more southward location of the tropical rain belt during the December-February season.

The Coupled Model Intercomparison Project (CMIP5) provides the coupled model data analysed in this study (Taylor et al. 2012). A sample of 19 models (Table 1) was chosen based on the availability of required variables: rainfall, surface temperature, sea surface temperature (SST), specific humidity, surface pressure, geopotential height, $u$ and $v$ winds and omega. Where there are multiple models from the same modelling group, only one version is used. All variables in all models are interpolated to a common grid of $1^{\circ} \times 1^{\circ}$, for ease of comparison; this does not affect the results. Data are taken from both the historical experiment and the future experiment with the highest emission forcings (and thus largest temperature increases), RCP8.5, which represents a global net radiative forcing of $8.5 \mathrm{~W} \mathrm{~m}^{-2}$ by 2100 (roughly a 'business as usual' scenario) (van Vuuren et al. 2011).

Rainfall change in models is calculated by subtracting the historical end of twentieth century mean (1979-2005) from the RCP8.5 end of twenty-first century mean (2074-2100) for any given variable. Composite analysis is used to identify the processes of importance in the extreme ends of the ensemble rainfall response. Composites are created of the four models at each end of the spectrum of rainfall responses; in DJF, this is the four models which show the most wetting ('wettest' composites) and the least wetting ('driest' composites); these are shown in Fig. 3.

Two methods are used to identify the robustness of signals in the figures. First, stipples are used when comparing the historical and RCP8.5 fields in a single composite and indicate where all models in the composite agree on the sign of change of the variable. This method is widely used, including in the IPCC assessment reports, and is a useful initial assessment of model agreement. Second, stipples are used when comparing two different composites, to signify areas where the values of the variable are distinct between the composites. This gives an indication of the robustness of the differences between composites. This metric, from Creese and Washington (2018) is more appropriate than using a t-test, given the small sample size.

The paper is structured as follows. Section 3 will provide an overview of the spectrum of rainfall changes in the Congo Basin across all seasons. Section 4 examines the spatial patterns of rainfall change across models, 
Table 1 CMIP5 models used in this study

\begin{tabular}{|c|c|}
\hline Model & Institute \\
\hline ACCESS1-3 & Commonwealth Scientific and Industrial Research Organization and Bureau of Meteorology Australia (CSIRO-BOM) \\
\hline bcc-csm1-1 & Beijing Climate Centre (BCC) \\
\hline CCSM4 & National Centre for Atmospheric Research (NCAR) \\
\hline CESM1-CAM5 & National Centre for Atmospheric Research (NCAR) \\
\hline CMCC-CM & Centro Euro-Mediterraneo per I Cambiamenti Climatici (CMCC) \\
\hline CNRM-CM5 & $\begin{array}{l}\text { Centre National de Recherches Météorologiques/Centre Européen de Recherche et Formation Avancée en Calcul Scienti- } \\
\text { fique (CNRM-CERFACS) }\end{array}$ \\
\hline CSIRO-Mk3-6-0 & $\begin{array}{l}\text { Commonwealth Scientific and Industrial Research Organization in collaboration with Queensland Climate Change Centre } \\
\text { of Excellence (CSIRO-QCCCE) }\end{array}$ \\
\hline EC-EARTH & EC-Earth Consortium: European Centre for Medium-Range Weather Forecasts (ECMWF) and other European institutes \\
\hline FGOALS-g2 & $\begin{array}{l}\text { State Key Laboratory of Numerical Modeling for Atmospheric Sciences and Geophysical Fluid Dynamics (LASG) and } \\
\text { Institute of Atmospheric Physics (IAP) }\end{array}$ \\
\hline FIO-ESM & First Institute of Oceanography, Qingdao (FIO) \\
\hline GFDL-CM3 & NOAA Geophysical Fluid Dynamics Laboratory (NOAA GFDL) \\
\hline GISS-E2-R & NASA Goddard Institute for Space Studies (GISS) \\
\hline HadGEM2-ES & Met Office Hadley Centre (MOHC) \\
\hline inmcm4 & Institute of Numerical Mathematics of the Russian Academy of Sciences (INM RAS) \\
\hline IPSL-CM5A-MR & Institut Pierre-Simon Laplace (IPSL) \\
\hline MIROC5 & $\begin{array}{l}\text { Atmosphere and Ocean Research Institute (The University of Tokyo), National Institute for Environmental Studies, and } \\
\text { Japan Agency for Marine-Earth Science and Technology (MIROC) }\end{array}$ \\
\hline MPI-ESM-LR & Max-Planck-Institut für Meteorologie(MPI-M) \\
\hline MRI-CGCM3 & Meteorological Research Institute (MRI) \\
\hline NorESM1-M & Norwegian Climate Centre (NCC) \\
\hline
\end{tabular}

focusing on the dry season DJF, which shows the strongest wetting signal across the majority of the basin. In Sect. 5, we assess model differences in the large-scale vertical circulation, and in Sect. 6 we examine differences in low-level horizontal circulation between models. We discuss the results and summarise in Sect. 7.

\section{Rainfall change across the annual cycle}

Rainfall in the Congo Basin is distributed bi-modally in the annual cycle, with two wet seasons [March-May (MAM) and September-November (SON)] and two dry seasons [June-August (JJA) and December-February (DJF)]. Coupled models are able to broadly capture this distribution in the historical simulation (1979-2005), with peak SON
Fig. 1 Box plot of long term mean rainfall $\left(\mathrm{mm} \mathrm{month}^{-1}\right)$ across CMIP5 models in the historical (1979-2005; red) and future (2074-2100; blue) periods for each month, averaged over $8^{\circ} \mathrm{E}-35^{\circ} \mathrm{E}, 10^{\circ} \mathrm{S}-10^{\circ} \mathrm{N}$

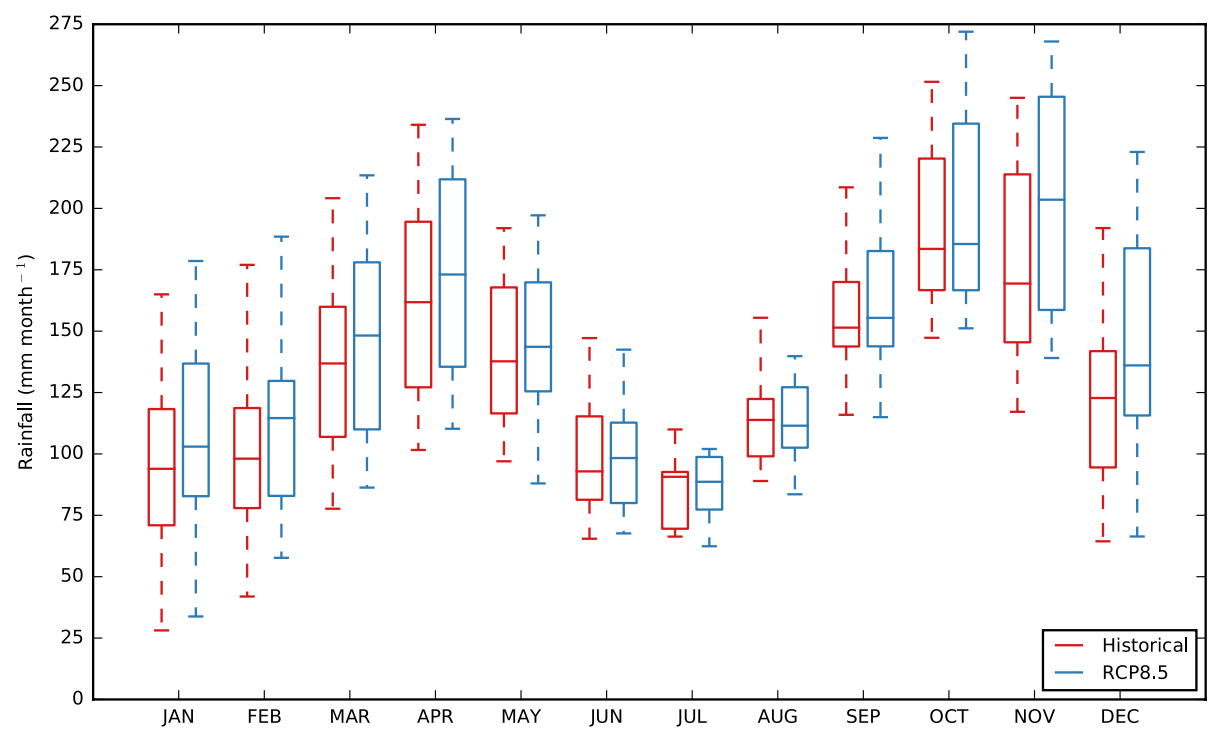




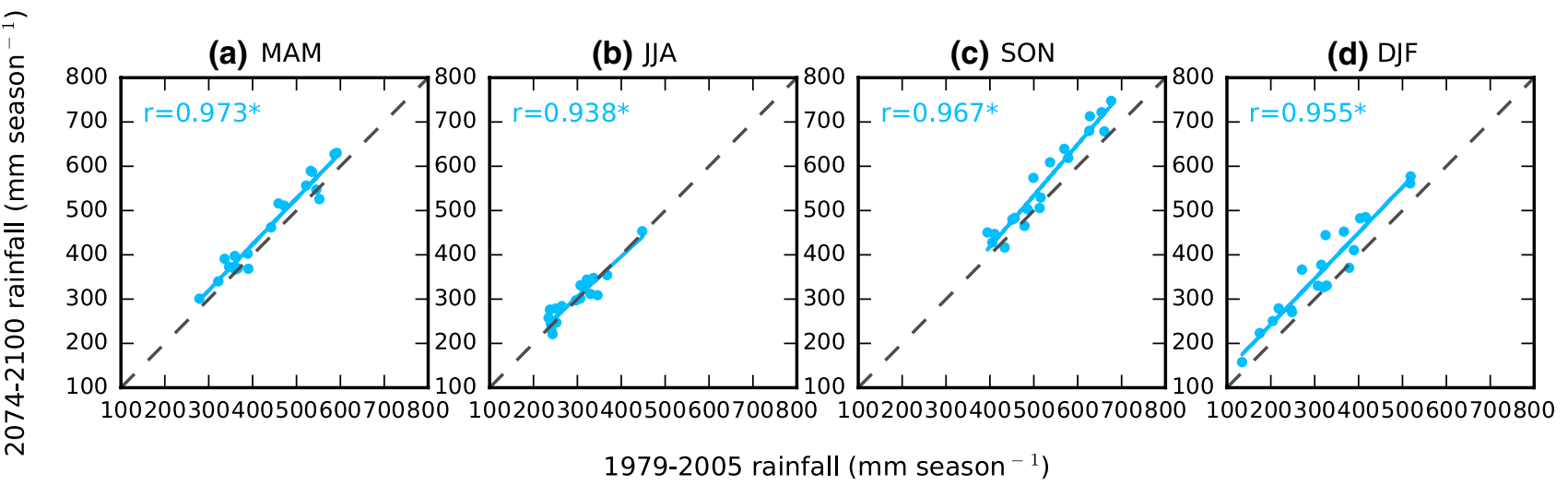

Fig. 2 Scatterplots of long term mean rainfall $\left(\mathrm{mm} \mathrm{season}^{-1}\right)$ in the future (2074-2100, RCP8.5) and historical (1979-2005) periods, averaged over $8^{\circ} \mathrm{E}-35^{\circ} \mathrm{E}, 10^{\circ} \mathrm{S}-10^{\circ} \mathrm{N}$. Asterisks indicate r-values significant at the $99.9 \%$ level

(MAM) rainfall occurring in October (April) (Fig. 1). This pattern is largely similar in the future simulations (2074-2100), although peak median rainfall in the SON rainy season shifts to November. There is a general pattern of future wetting: in ten out of 12 months, the median model value in the future simulation is greater than that in the present. In addition, in seven out of 12 months, both the upper and lower limits of the range increase in the future compared to the historical simulation. These results fit with previous research based on MMEs of coupled GCMs, which have indicated that the Congo Basin will get slightly wetter in the future (Haensler et al. 2013; Aloysius et al. 2016).

The positive shift in the median values of rainfall is small compared to the large spread of model values in each month, which, in some months, can differ by a factor of five (Creese and Washington 2016). This inter-model spread of simulated rainfall persists in the future simulations, and in nine out of 12 months, the inter-quartile range of the future values exceeds that of the historical values, indicating increasing divergence amongst the coupled models mean rainfall in the future. Nevertheless, between October and May the two historical and future samples show significant differences using a paired Students t-test $(\mathrm{p}<0.05)$ with the largest and most significant differences between November and April ( $p<0.001)$. In all of these months, the median, inter-quartile range, and upper and lower limits are shifted positively in the future simulations. Differences between the two simulations are insignificant at 95\% in the JJA dry season and September. In addition, Fig. 2 shows that while model rainfall values tend to be shifted towards wetter values in most seasons, especially DJF, model wetness is strongly correlated between the historical and future periods.

\section{Rainfall change in DJF}

Given that DJF features the largest and most consistent signal of any season, and given the importance of the dry seasons in this region, we focus on this signal to demonstrate a general process-based methodology for examining intermodel differences of rainfall change. To assess the likely rainfall changes in this season, we focus on a smaller domain than in previous figures $\left(10^{\circ} \mathrm{E}-35^{\circ} \mathrm{E}, 10^{\circ} \mathrm{S}-5^{\circ} \mathrm{N}\right.$, green box in Fig. 4), which comprises the core of the tropical rain-belt over the Congo Basin during this season.

\subsection{All models}

All but one model features mean wetting in DJF across the smaller domain (Fig. 3). However, there are relatively large differences in the mean $\Delta P$ values in each model; inmcm 4 exhibits only $2.3 \mathrm{~mm}$ season $^{-1}$ wetting, whereas ACCESS1-3 features $160.4 \mathrm{~mm}^{\text {season }}{ }^{-1}$. Figure 3 also highlights the lack of correlation between $\Delta P$ (blue bars) and historical model rainfall (red bars); i.e. the historically wet (drier) models do not get wetter (less wet/dry) $(r=0.107$, $\mathrm{p}=0.66$ ). This is interesting to note as a predominantly thermodynamic understanding of rainfall change would suggest that models with high rainfall already will get relatively wetter in future. This implies that other mechanisms may better describe the spectrum of model rainfall responses.

Figure 3 also highlights that the values of $\Delta P$ are small compared to the mean historical rainfall in all models; the magnitude of $\Delta P$ accounts for between $0.54 \%$ (inmcm4) and $37.67 \%$ (ACCESS1-3) of historical rainfall across individual models. In addition, the differences in historical rainfall between models are in many cases larger $\Delta P$; for example, in the historical mean NorESM1-M (660.7 mm season $\left.{ }^{-1}\right)$ 
Fig. 3 Long term mean DJF rainfall $\left(\mathrm{mm} \mathrm{season}^{-1}\right)$ in the historical period (1979-2005; red) and future (2074-2100) minus historical rainfall change $(\Delta P$; blue $)$ in individual CMIP5 models, averaged over $10^{\circ} \mathrm{E}-35^{\circ} \mathrm{E}, 10^{\circ} \mathrm{S}-5^{\circ} \mathrm{N}$. Models are displayed in order of $\Delta P$ values (low to high). Models used in the wettest (driest) composites in Sect. 4 onwards are denoted by hatching (stipples)

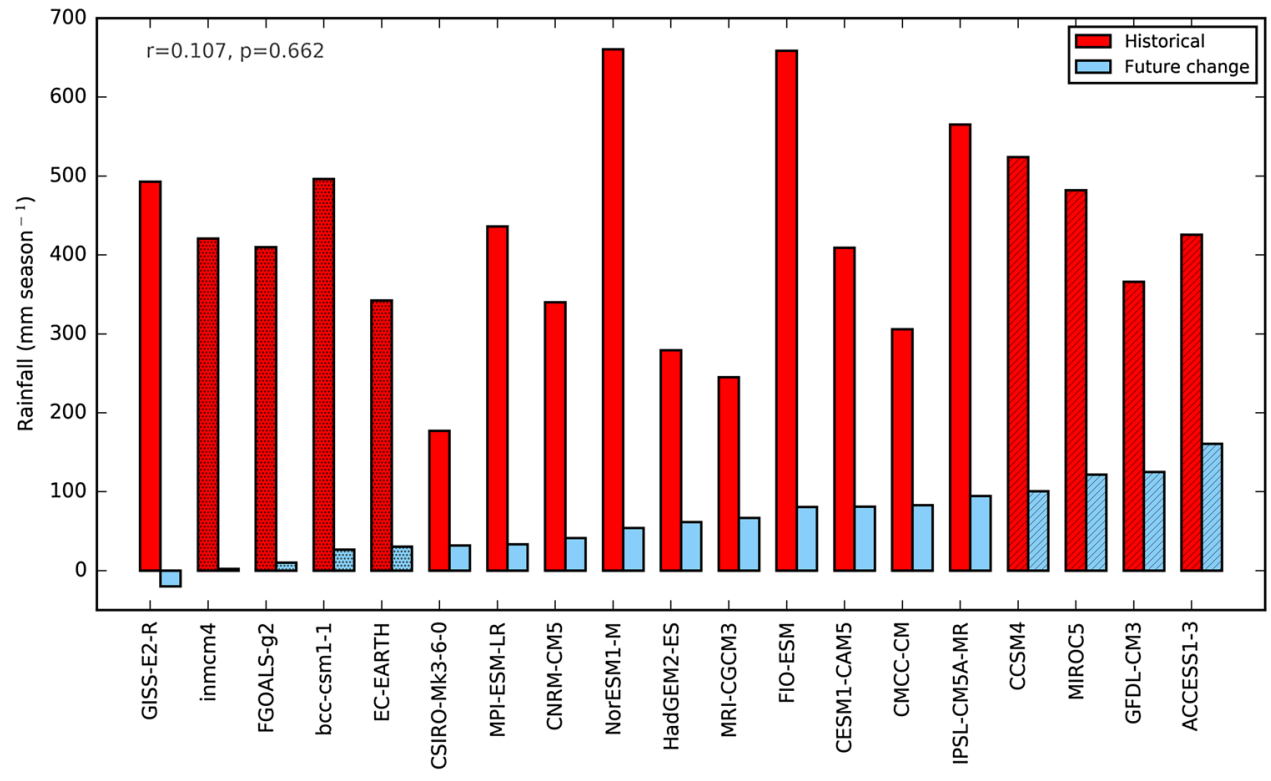

(a) $2074-2100$

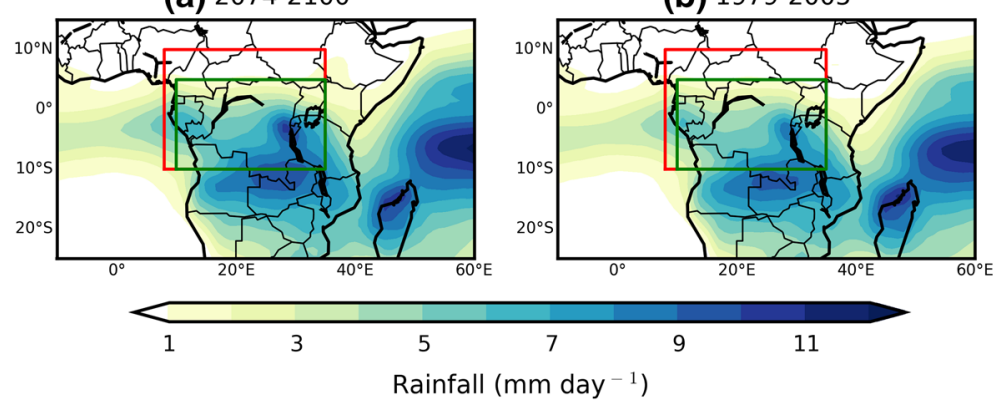

(c) $\Delta P$

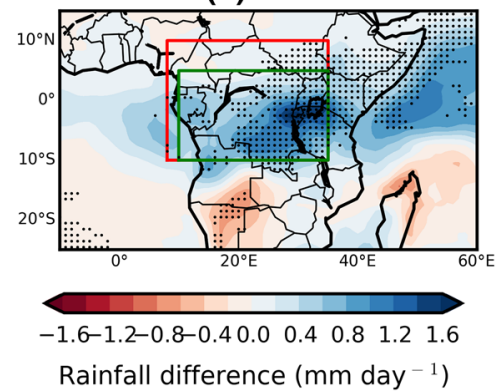

Fig. 4 Long term mean DJF rainfall $\left(\mathrm{mm} \mathrm{day}^{-1}\right.$ ) in a 2074-2100, b 1979-2005 and $\mathbf{c} \Delta P$. The red (green) box is the location of the $8^{\circ} \mathrm{E}-35^{\circ} \mathrm{E}$, $10^{\circ} \mathrm{S}-10^{\circ} \mathrm{N}\left(10^{\circ} \mathrm{E}-35^{\circ} \mathrm{E}, 10^{\circ} \mathrm{S}-5^{\circ} \mathrm{N}\right)$ domain. Stipples in $\mathbf{c}$ indicate where 15 out of 19 models agree on the sign of change

is almost $500 \mathrm{~mm}$ season ${ }^{-1}$ wetter than CSIRO-Mk3-6-0 $\left(177.0 \mathrm{~mm} \mathrm{season}^{-1}\right)$, which is more than double even the largest $\Delta P$ value (ACCESS-1-3, $160.4 \mathrm{~mm}_{\text {season }}{ }^{-1}$ ).

Figure 4 shows the spatial distribution of rainfall in the future and historical simulations, and the future-minus-present difference. Despite heterogeneity in the future rainfall change for each season, the spatial pattern and quantity of rainfall is similar between the ensemble means of future and historical rainfall. Both simulations show two regions of climatological rainfall maxima: one at the DRC-Tanzania border near the equator, and the other at the southern boundary of the domain $\left(10^{\circ} \mathrm{S}\right)$. Previous work has indicated there are large disparities between models on the location of maximum rainfall, with some models showing rainfall predominantly in the east or west of the basin, particularly in the wet seasons (Creese and Washington 2016, 2018). The similarities between future and historical rainfall distributions are also evident in individual models; e.g., models which feature their rainfall maximum in the east in the historical simulation also do so in the future (not shown). Alongside the strong correlations in Fig. 2, this further suggests that a model's historical climatology relates to the future climatological rainfall magnitude and distribution in this region, meaning that present-day biases could affect the location or magnitude of rainfall change.

There is some consistency in the spatial pattern of the rainfall change signal across models (Fig. 5). Most models show wetting across the majority of the domain (green box), in particular in the east, where $\Delta P$ is largest. Some models show areas of negative $\Delta P$ in the north (e.g., MPI-ESM-LR) and west (e.g., inmcm4, FGOALS-g2, bcc-csm1-1). Most models also feature some drying to the south of the domain and wetting to the east of the domain and over the WIO. However, there are large inconsistencies in the magnitude of $\Delta P$ across models, even where the signal remains the same. For example, wetting in the east Congo Basin reaches 

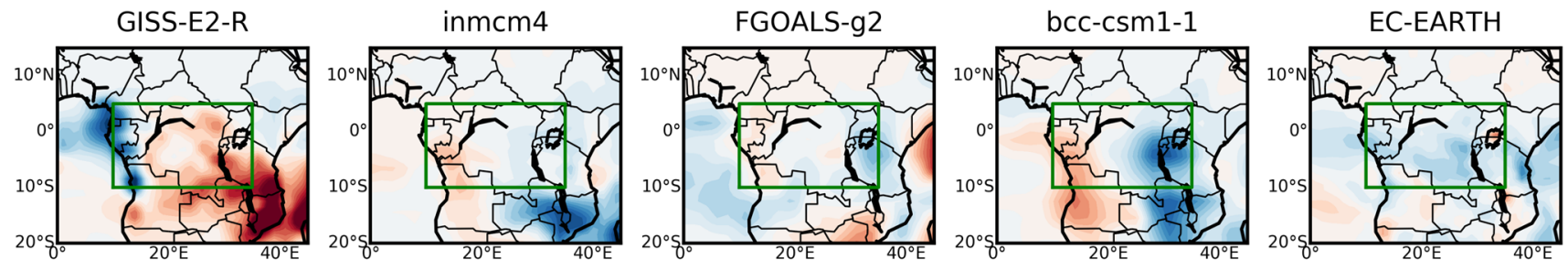

CSIRO-Mk3-6-0

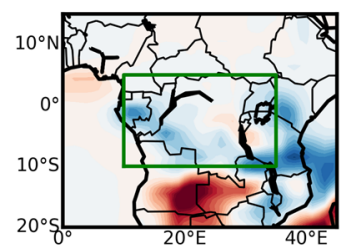

MPI-ESM-LR

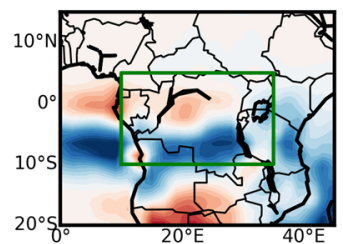

CNRM-CM5

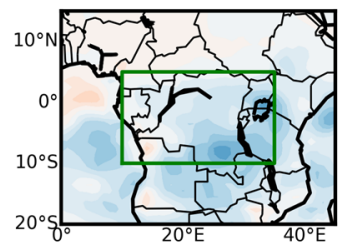

NorESM1-M

HadGEM2-ES

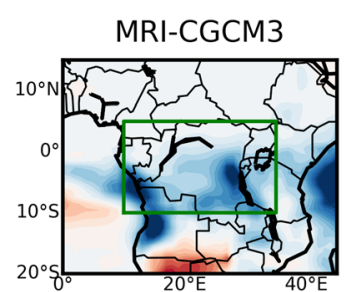

FIO-ESM

CESM1-CAM5
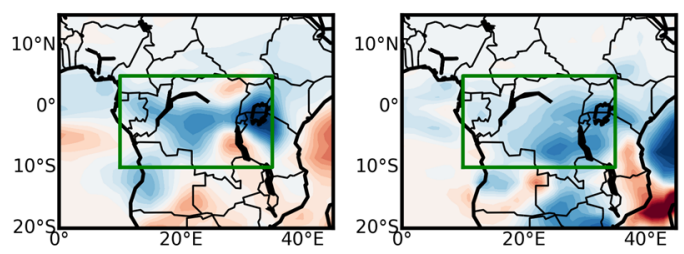

CMCC-CM
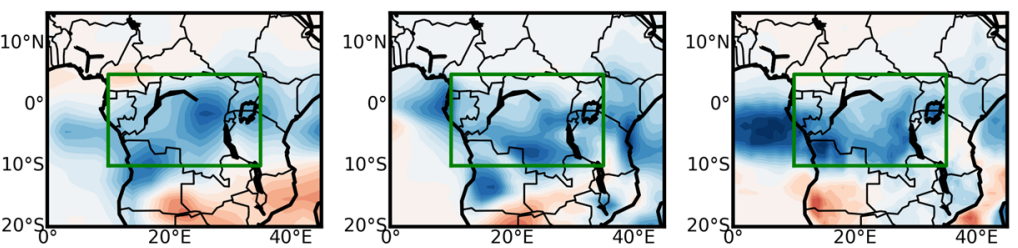

IPSL-CM5A-MR
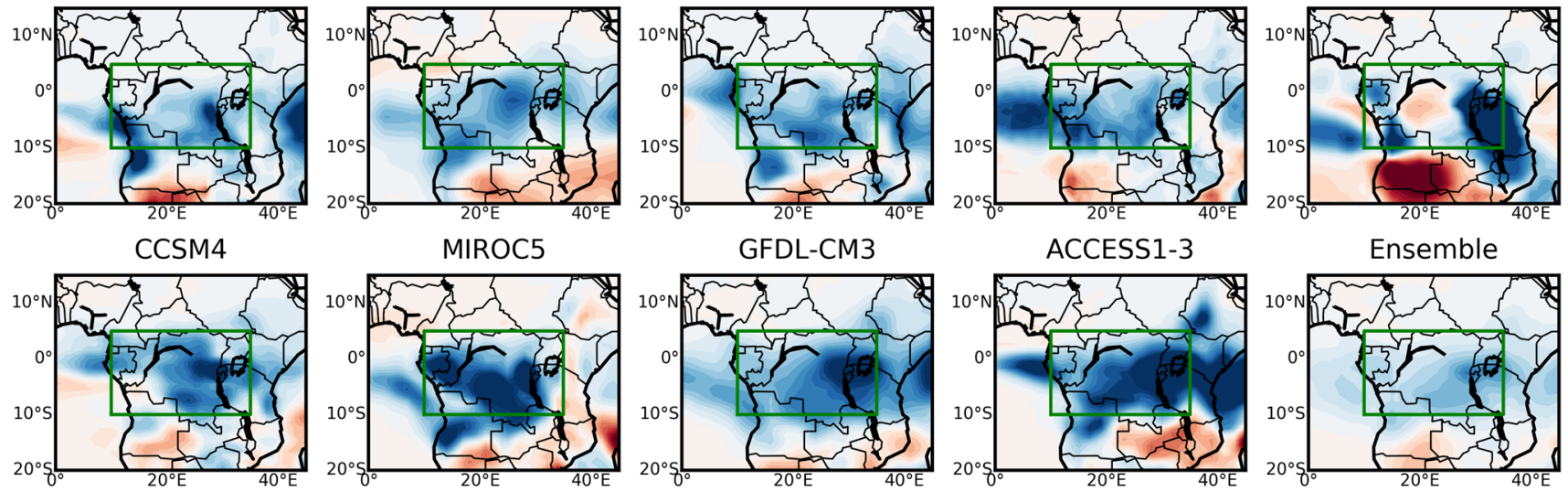

Ensemble

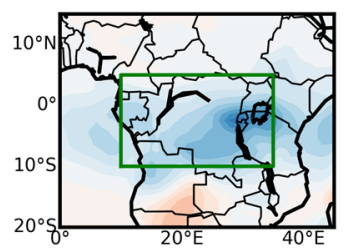

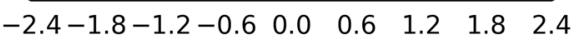

Rainfall difference ( $\mathrm{mm}$ day ${ }^{-1}$ )

Fig. 5 DJF $\Delta P\left(\mathrm{~mm} \mathrm{day}^{-1}\right)$ in individual CMIP5 models, ordered by mean $\Delta P$ (low to high) calculated over the domain $10^{\circ} \mathrm{E}-35^{\circ} \mathrm{E}, 10^{\circ} \mathrm{S}-5^{\circ} \mathrm{N}$ (green box)

$8.15 \mathrm{~mm} \mathrm{day}^{-1}$ in IPSL-CM5A-LR, whereas the maximum in inmcm4 is only reaches $0.68 \mathrm{~mm}$ day $^{-1}$.

The one model that features mean drying, GISS-E2-R, has previously been found to have an anomalous climatology in this region, both in terms of rainfall magnitude and distribution. Whilst the majority of models broadly feature maximum rainfall in south-east Congo Basin in this season, matching reanalysis and satellite datasets, in GISS-E2-R rainfall hugs the Atlantic coast in all seasons, rarely extending into the continent. Because of its vastly different historically climatology and $\Delta P$ signal, GISS-E2-R has been excluded from the composite analysis in the following figures.

Figure 6 shows how the patterns of changing rainfall fit into the latitudinal annual cycle of rainfall in the ensemble mean. A north-wetting, south-drying pattern is evident between October and December (as anticipated from Fig. 4). Enhanced wetting is present in the ensemble mean of models beginning in July at around $15^{\circ} \mathrm{N}$, and continues through the annual cycle until April in the south of the Congo Basin domain. Further south, there is future drying throughout much of the annual cycle, which is strongest between October and January. Figure 6 indicates that the wetting over the Congo Basin during DJF cannot be properly described as a delay in the southward movement of the rain band, as Fig. 4 may have suggested, as there is not a subsequent wetting over southern Africa from February onwards, as would be expected with such a delay. Instead, there is concurrent wetting over the Congo Basin and drying over southern Africa between October and December, suggesting that the rain band stops further north than in the historical period, and is more intense over the Congo Basin.

\subsection{Composites}

To understand how patterns of $\Delta P$ differ across the spectrum of models, Fig. 7 shows model future rainfall, historical 

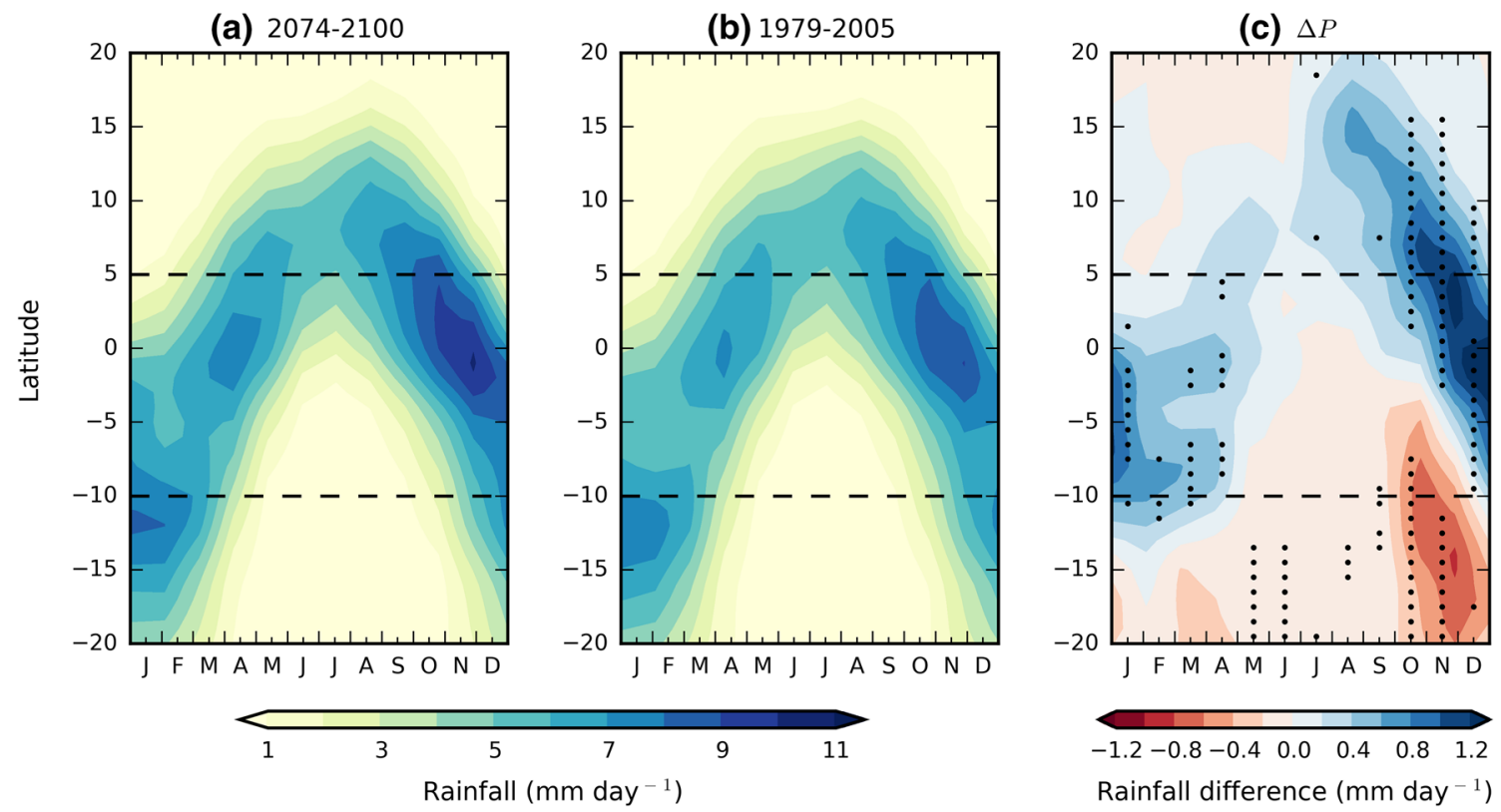

Fig. 6 Annual cycle of long term mean rainfall $\left(\mathrm{mm} \mathrm{day}^{-1}\right)$ averaged between $10^{\circ} \mathrm{E}$ and $35^{\circ} \mathrm{E}$, in a 2074-2100, b $1979-2005$ and $\mathbf{c} \Delta P$. Dashed lines denote the northern and southern boundaries of the domain. Stipples as in Fig. 4 caption

rainfall and $\Delta P$ in the wettest and driest composites (as defined in Sect. 2). Both the wettest and driest composites have reasonably similar rainfall climatologies in both the future and historical simulations (column one and two); rainfall is highest in the south and east of the domain, with the rainfall band extending into southern Africa. Both composites also feature areas of high rainfall over the WIO and north Madagascar, though this region is further south and east in the driest composite.

However, the distribution of $\Delta P$ is quite different between the two composites (column three). In the wettest models, rainfall increases across almost the entire domain, in some places exceeding $2 \mathrm{~mm} \mathrm{day}^{-1}$ in the composite mean. Models within the wettest composite agree on the sign of change across the whole domain, except for a small area in the south west over north Angola. In addition to wetting over the Congo Basin, these models also show robust wetting over the East African coast and coastal WIO and drying over the northern tip of Madagascar. This is suggestive of a northward shift and change in intensity of the WIO wet region, and possible concurrent changes in the dynamics of the reversed Asian monsoon flow during this season.

In contrast, in the driest composite there is less consistency in the response over the Congo Basin. All models feature low magnitude wetting in the east and south of the basin, but in the west of the basin models don't all agree on the sign of change. From Fig. 5 we can see that three out of four of the driest models show slight drying in the west, whilst EC-EARTH shows weak wetting. However, the magnitudes of these changes are very low $\left(<1 \mathrm{~mm} \mathrm{day}^{-1}\right)$.
In contrast to the wettest composite, the driest composite doesn't feature consistent wetting over the WIO, and features some wetting near northern Madagascar. This again suggests changes in the circulation dynamics over the west Indian Ocean. Over the Congo Basin, the most consistent differences between the two composites are in the central and eastern portions of the Congo Basin domain (Fig. 7g, larger stipples). Figure $7 \mathrm{~g}$ also highlights an anomalous north-south pattern between the two composites, whereby the wettest models show enhanced wetting over the Congo Basin and the WIO, and the driest models feature greater wetting over Mozambique and northern Madagascar.

\section{Changes in large-scale vertical circulation}

To better understand the large-scale tropical context in which these changes occur, in this section we examine the changes in vertical circulation that occur in the two composites. Wetting over the Congo Basin, a convective hotspot, will require changes in uplift and subsidence elsewhere, and examining this will help our understanding of how Congo Basin rainfall change is a part of the wider global warming signal.

In the meridional cross-section, the wettest and driest composites feature quite different patterns of futureminus-present change in omega $(\Delta \Omega)$ (Fig. 8). In the wettest, uplift increases between roughly $5^{\circ} \mathrm{S}$ and $5^{\circ} \mathrm{N}$, with the largest mean increase at the equator at $500 \mathrm{hPa}$ (Fig. 8c). Further south, at around $15^{\circ} \mathrm{S}$, there is a decrease 
(a) Wettest 2074-2100

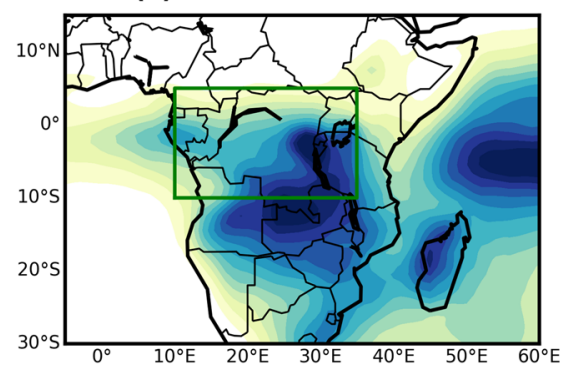

(d) Driest 2074-2100

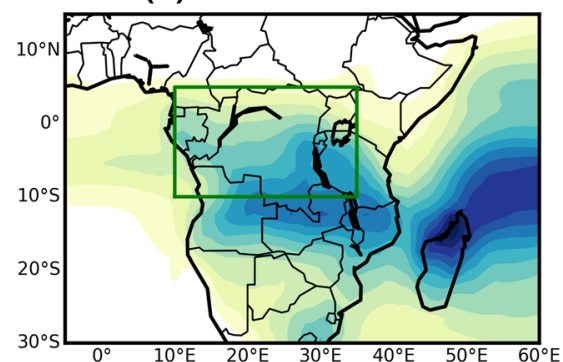

(b) Wettest 1979-2005

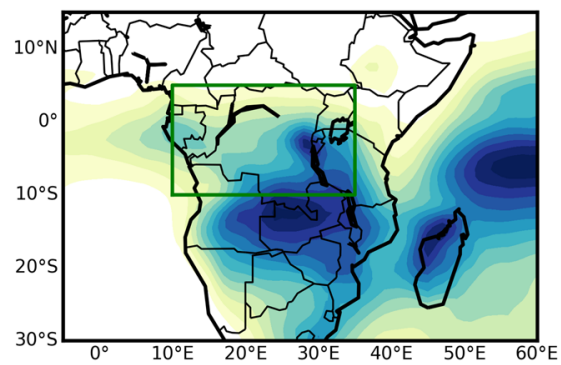

(e) Driest 1979-2005

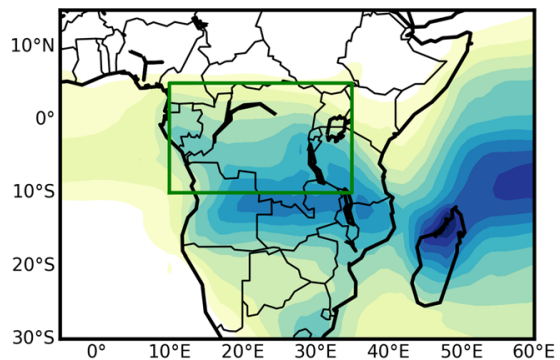

(c) Wettest $\Delta P$

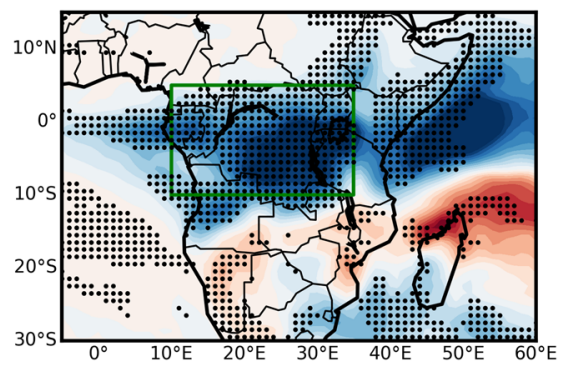

(f) Driest $\Delta P$

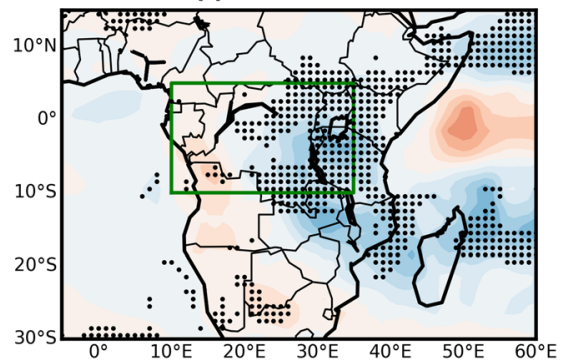

(g) Wettest $\Delta P$ minus Driest $\Delta P$

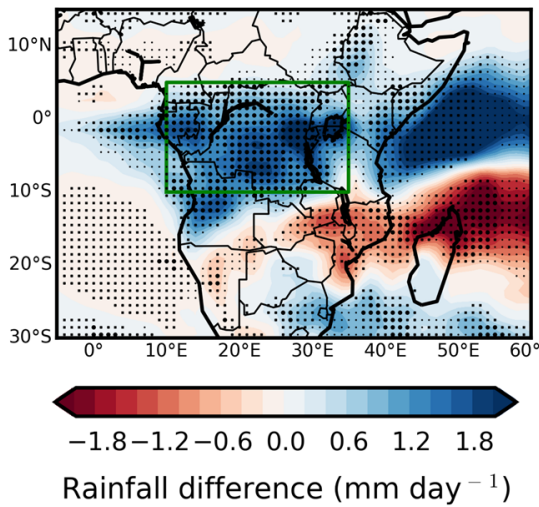

Fig. 7 Long term mean DJF rainfall $\left(\mathrm{mm} \mathrm{day}^{-1}\right)$ in the wettest composite (top row) and the driest composite (middle row) in: a, d 2074-2100; b, e 1979-2005; and c, f $\Delta P$; $\mathbf{g}$ wettest composite $\Delta P$ minus driest composite $\Delta P$. Stipples in $\mathbf{c}$ and $\mathbf{f}$ indicate where all four models in the composite agree on the sign of change. Stipples in $\mathbf{g}$ occur at gridboxes where: (1) all wettest composite values are larger or smaller than all driest composite values (large dots); (2) all wettest composite values are greater or smaller than the driest composite mean (squares); (3) driest composite values are greater or smaller than the wettest composite mean (crosses); and (4) both (2) and (3) are true (small dots)

decrease in uplift, particularly above $600 \mathrm{hPa}$. Further north there is increased low-level uplift and decreased upper level subsidence at $10^{\circ} \mathrm{N}$, though as this is not a region of deep convection it is unlikely to be related to collocated rainfall changes. This composite also features an increase in subsidence north of $30^{\circ} \mathrm{N}$, though much weaker in magnitude than in the wettest models. Overall, the difference in $\Delta P$ between the two composites is well supported by the difference in $\Delta \Omega$ (Fig. 8g), which shows models with the wettest (driest) change feature anomalously stronger uplift (subsidence) across the entire Congo Basin domain.

In the zonal cross-section, as in the meridional cross-section, $\Delta \Omega$ is negative (more uplift) over the Congo Basin in 
(a) Wettest 2074-2100

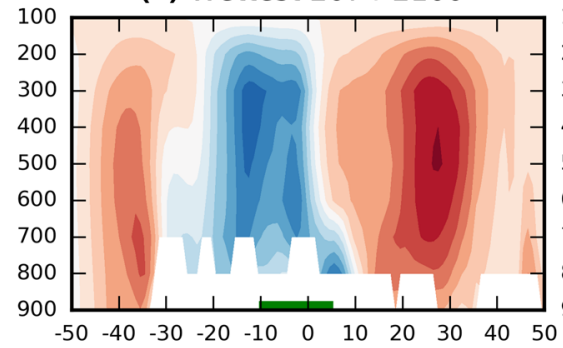

(d) Driest 2074-2100

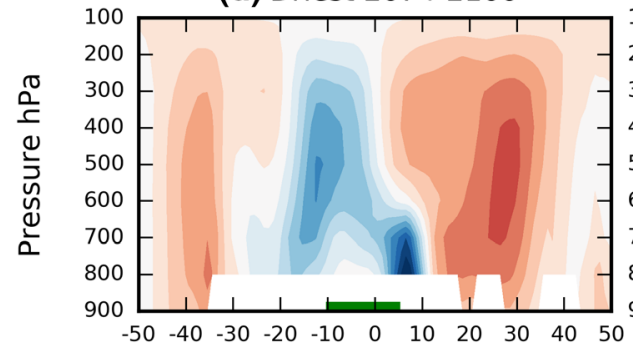

(b) Wettest 1979-2005

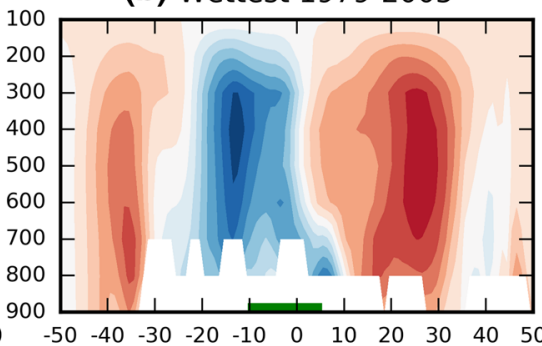

(e) Driest 1979-2005

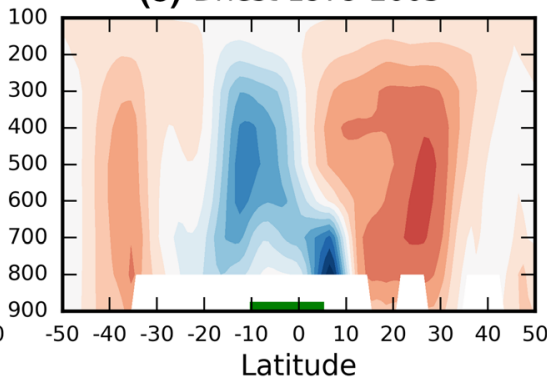

(c) Wettest $\Delta \Omega$

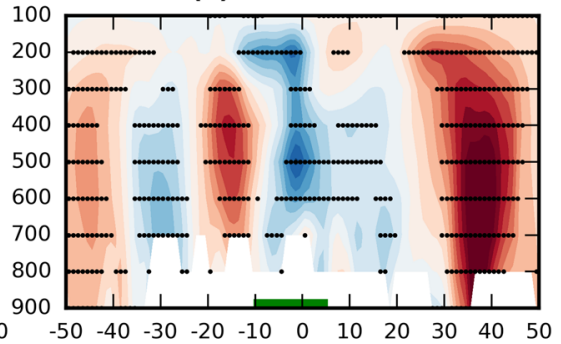

(f) Driest $\Delta \Omega$

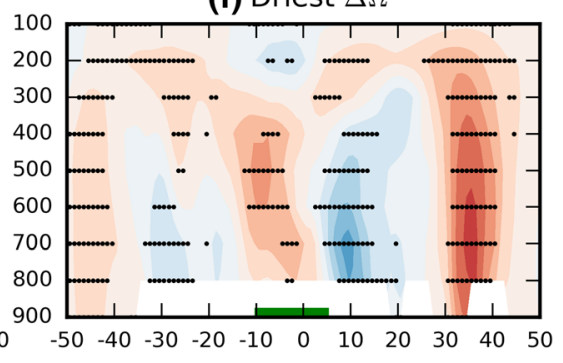

(g) Wettest $\Delta \Omega$ minus Driest $\Delta \Omega$

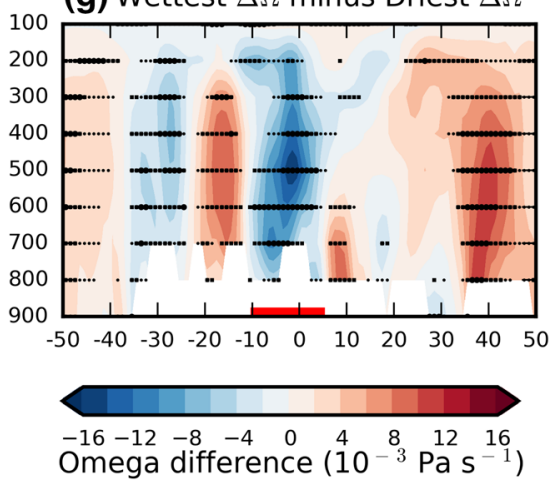

Fig. 8 Long term mean DJF omega $\left(\Omega, 10^{-3} \mathrm{~Pa} \mathrm{~s}^{-1}\right)$ averaged between $10^{\circ} \mathrm{E}$ and $35^{\circ} \mathrm{E}$, in the wettest composite (top row) and the driest composite (middle row) in: a, d 2074-2100; b, e 1979-2005; and $\mathbf{c}, \mathbf{f} \Delta \Omega$; $\mathbf{g}$ wettest composite $\Delta \Omega$ minus driest composite $\Delta \Omega$.

the wettest composite and positive (less uplift) in the driest composite (Fig. 9). In the wettest composite, there is a gap at around $35^{\circ} \mathrm{E}$ between enhanced uplift over the Congo Basin, and enhanced uplift/decreased subsidence over the East African coast at $40^{\circ} \mathrm{E}$. There is a significant decrease in uplift in the east Indian Ocean in the warm pool region, as well a reduction in upward motion in the central Indian Ocean. In the driest composite, the patterns over the Indian Ocean are similar but much weaker in magnitude. The anomalous uplift in the west and anomalous subsidence in the east is reminiscent of the atmospheric response to a positive Indian Ocean Dipole (IOD) event, where warmer-than average SSTs in the WIO contribute to enhanced convection and thus rainfall. It could also be related to changes in the wider Walker cell, as several studies have suggested that the Pacific indirectly forces changes in SSTs over the Indian Ocean (Goddard and Graham 1999;
Areas with high topography in models are masked (white). The green box shows the extent of the Congo Basin domain $\left(10^{\circ} \mathrm{E}-35^{\circ} \mathrm{E}\right)$. Stipples are as described in Fig. 7 caption

Black et al. 2003). An overall weakening of the tropical zonal overturning cell has been identified in many previous studies as a consequence of warming. As this pattern is larger in the wettest composite (Fig. 9g), it suggests that these models may show a greater dynamical response to warming; this will be analysed further in Sects. 6 and 7.

\section{Low-level moisture flux changes}

In this section we assess the role of low-level circulation in explaining model differences in $\Delta P$. Low-level moisture flux $(q f l u x)$ has previously been found to differentiate between wet and dry models in this region in the historical period. Creese and Washington (2016) found that low-to-mid level qflux from the north and east is much stronger in wet models 
(a) Wettest 2074-2100

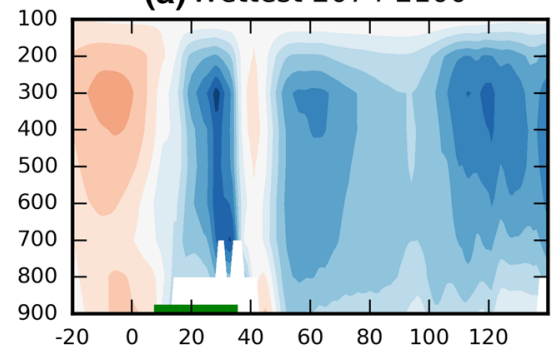

(d) Driest 2074-2100

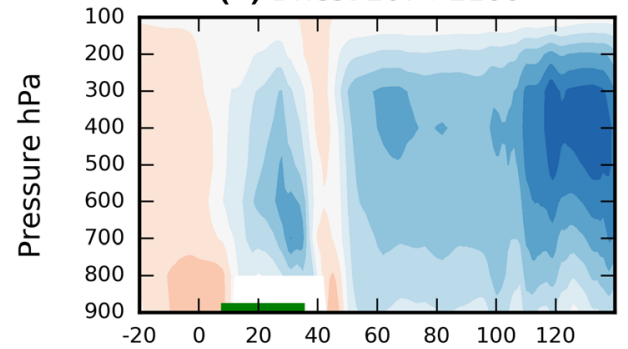

(b) Wettest 1979-2005

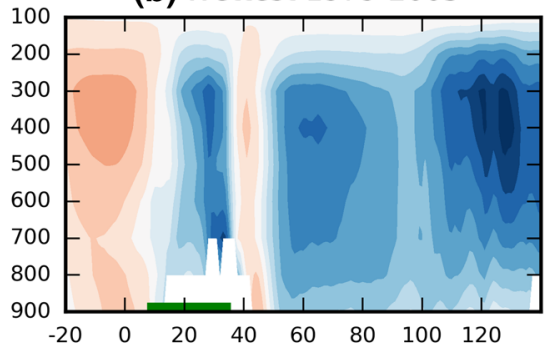

(e) Driest 1979-2005

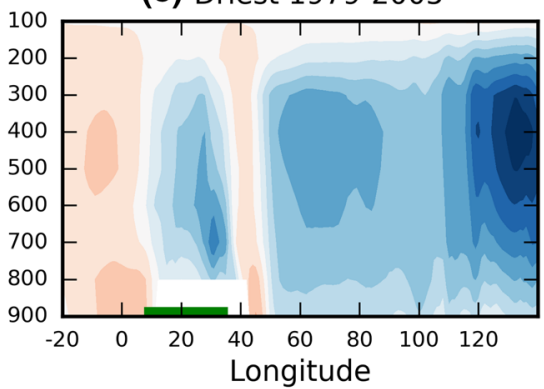

(c) Wettest $\Delta \Omega$

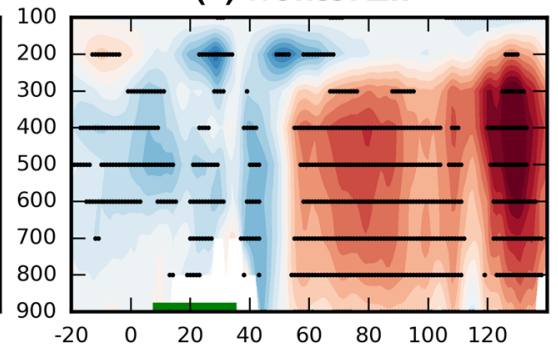

(f)Driest $\Delta \Omega$

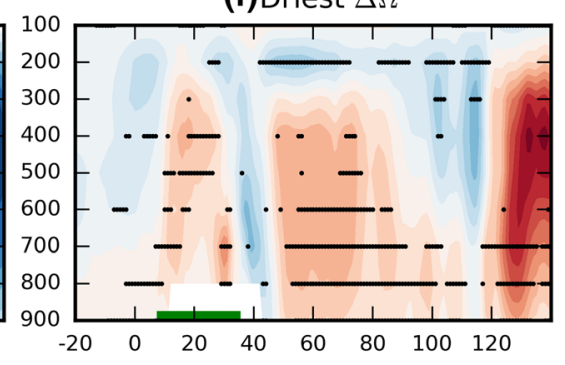

(g) Wettest $\Delta \Omega$ minus Driest $\Delta \Omega$

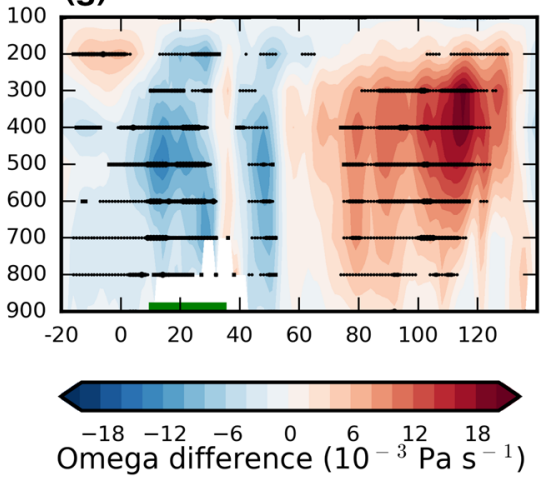

Fig. 9 Long term mean DJF omega $\left(10^{-3} \mathrm{~Pa} \mathrm{~s}^{-1}\right)$ averaged between $10^{\circ} \mathrm{S}$ and $5^{\circ} \mathrm{N}$, in the wettest composite (top row) and the driest composite (middle row) in: a, d 2074-2100; b, e 1979-2005; and c, f $\Delta \Omega$; $\mathbf{g}$ wettest composite $\Delta \Omega$ minus driest composite $\Delta \Omega$. Areas with

than dry models during DJF, suggesting that understanding the mechanisms behind these fluxes is important for establishing which models have a more realistic climatology. Similarly, Creese and Washington (2018) found that during the SON rainy season, low-level westerlies into the Congo Basin from the tropical Atlantic are enhanced in models with larger SST biases there, resulting in increased oceanic evaporation and convection over the west Congo Basin. Given the importance of $q f l u x$ in the historical climatologies therefore, it is a sensible place to begin understanding why $\Delta P$ differs across models. The qflux field at both $850 \mathrm{hPa}$ and $700 \mathrm{hPa}$ is analysed below. high topography in models are masked (white). The green box shows the extent of the Congo Basin domain $\left(10^{\circ} \mathrm{S}-5^{\circ} \mathrm{N}\right)$. Stipples are as described in Fig. 7 caption

\subsection{Moisture flux at $850 \mathrm{hPa}$}

The pattern of climatological qflux and qflux convergence at $850 \mathrm{hPa}$ in the historical period is broadly similar for both the wettest and driest composites (Fig. 10b, e). Water vapour flux into the basin is predominantly from the north east, embedded in the winds resulting from the reversal of the Asian Monsoon during DJF. In addition there is some lowlevel westerly flow from the south west, and moisture outflow in the south east corner of the domain. Both composites show convergence in the north and east of the domain, and divergence in the south west of the domain. The similarities between composite climatologies is in line with previous results from Creese and Washington (2016), who found that differences in rainfall across models were more associated 
(a) Wettest 2074-2100

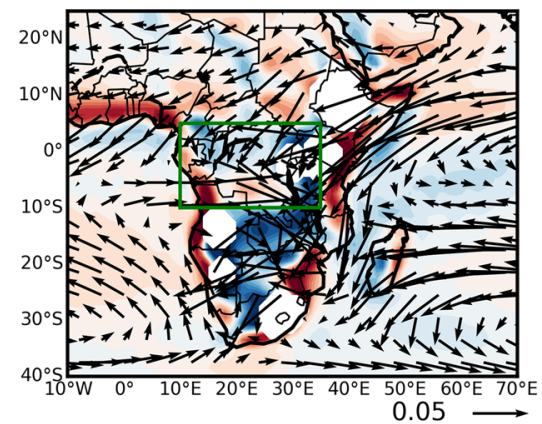

(d) Driest 2074-2100

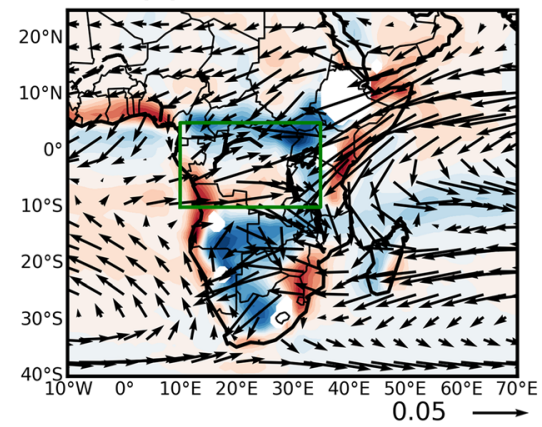

(b) Wettest 1979-2005

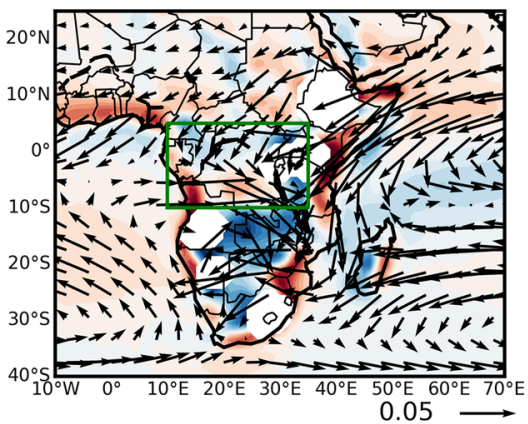

(e) Driest 1979-2005

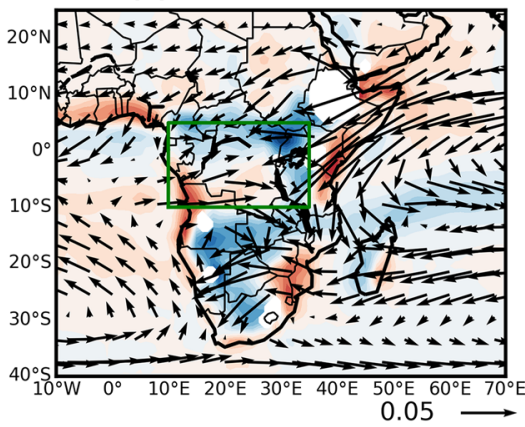

(c) Wettest $\Delta$

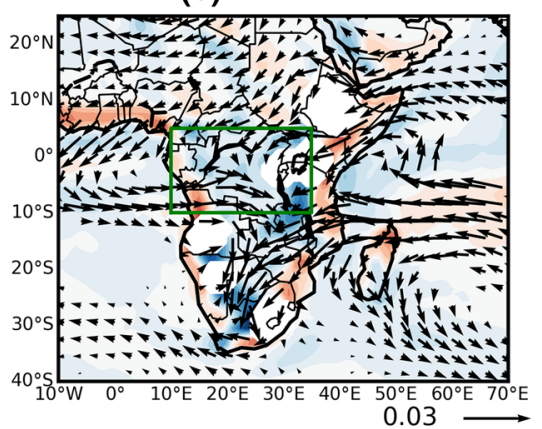

(f) Driest $\Delta$

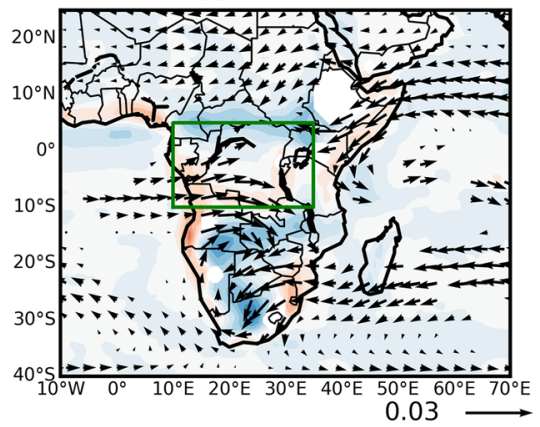

(g) Wettest $\Delta$ minus Driest $\Delta$

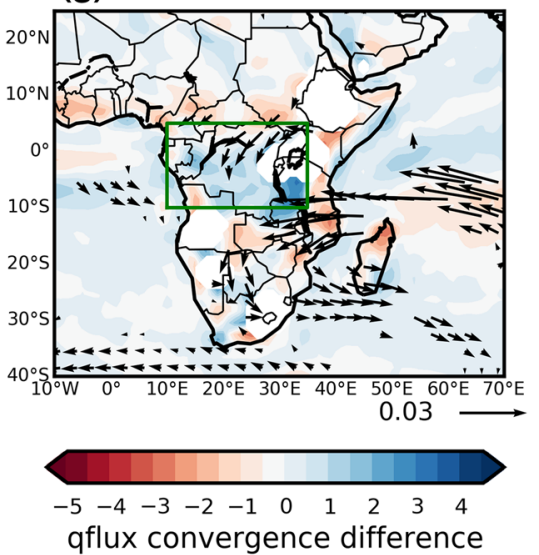

Fig. 10 Long term mean DJF qflux convergence $\left(10^{-8} \mathrm{~kg} \mathrm{~kg}^{-1} \mathrm{~s}^{-1}\right.$; shaded) and qflux ( $\mathrm{kg} \mathrm{kg}^{-1} \mathrm{~m} \mathrm{~s}^{-1}$; vectors) at $850 \mathrm{hPa}$ in the wettest composite (top row) and the driest composite (middle row) in: a, d 2074-2100; b, e 1979-2005; and c, f $\Delta q f l u x$ and $\Delta q f l u x$ convergence; g wettest composite minus driest composite $\Delta$ qflux and qflux conver- gence. Vectors in $\mathbf{c}$ and $\mathbf{f}$ are only present where all four models in the composite agree on the sign of change. Vectors in $\mathbf{g}$ are only present at gridboxes where all wettest composite values of $q u$ or $q v$ are larger or smaller than all driest composite values. The green box indicates the location of the $10^{\circ} \mathrm{E}-35^{\circ} \mathrm{E}, 10^{\circ} \mathrm{S}-5^{\circ} \mathrm{N}$ domain with the intensity of such circulation features, rather than distinct differences in the pattern of the qflux.

Both composites feature a similar distribution of $q f l u x$ and $q f l u x$ convergence in the future (Fig. 10), and both feature an enhancement of the continent-wide pattern of convergence and divergence. Future-minus-present $q f l u x$ convergence $(\Delta q$ conv) is positive in the north east-to-south west band across the continent, and negative (i.e., increased divergence) in along much of the east and west coasts. However, within and around the Congo Basin there are some key differences between the composites. While the wettest composite features increased convergence across the majority of the Congo Basin domain in the future, the driest composite features slightly enhanced divergence/weakened convergence over the Congo Basin. This positive relationship between $\Delta q \operatorname{conv}$ and $\Delta P$ holds across the whole suite of models; the correlation between mean $\Delta q$ conv and $\Delta P$ returns an r-value of 0.71 $(\mathrm{p}=0.0009)$. The wettest composite also features enhanced divergence over northern Madagascar and Mozambique, whereas the driest features enhanced convergence here. 
(a) Wettest 2074-2100

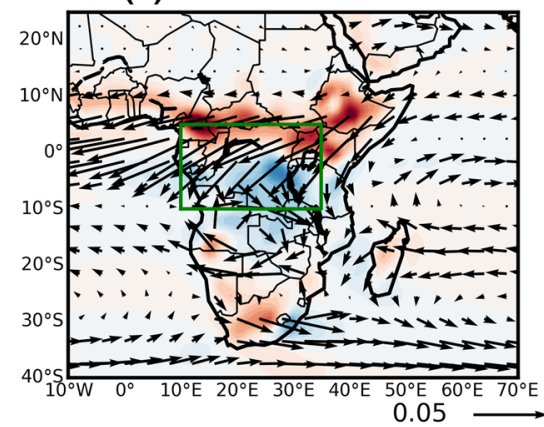

(d) Driest 2074-2100

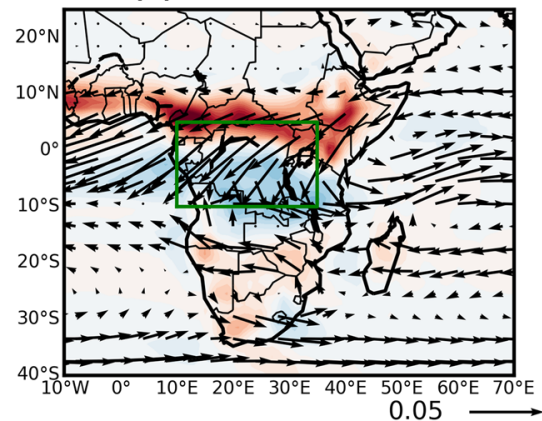

(b) Wettest 1979-2005

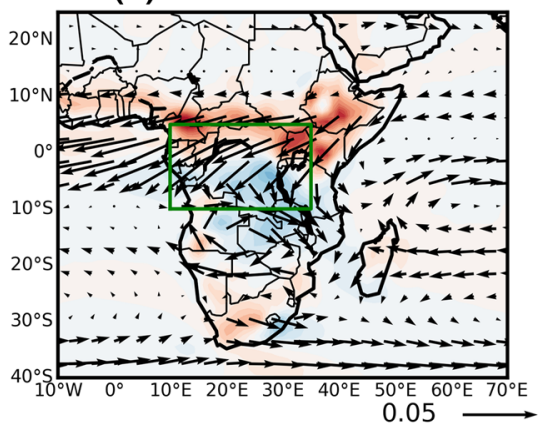

(e) Driest 1979-2005

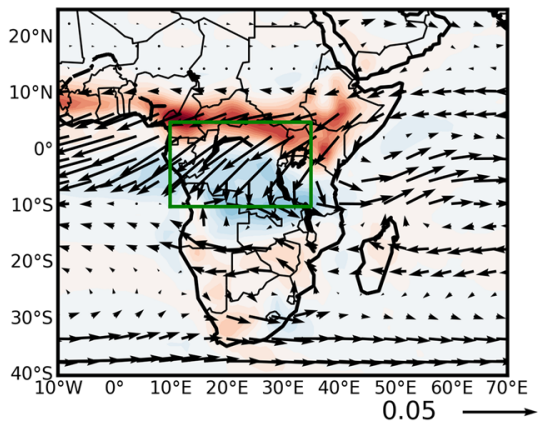

(c) Wettest $\Delta$

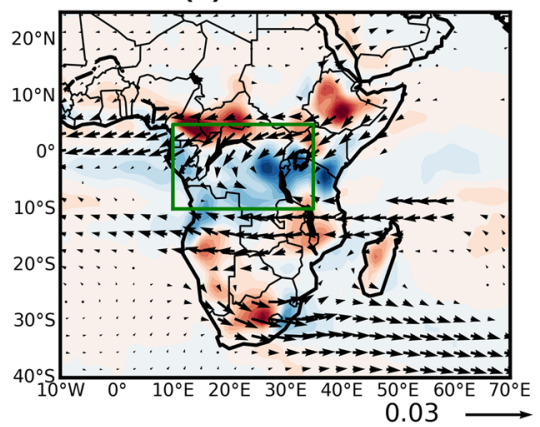

(f) Driest $\Delta$

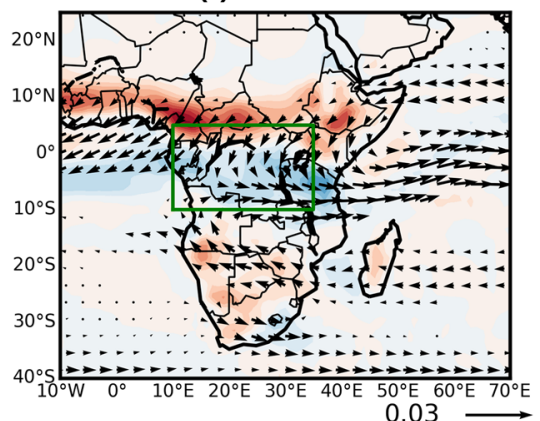

(g) Wettest $\Delta$ minus Driest $\Delta$

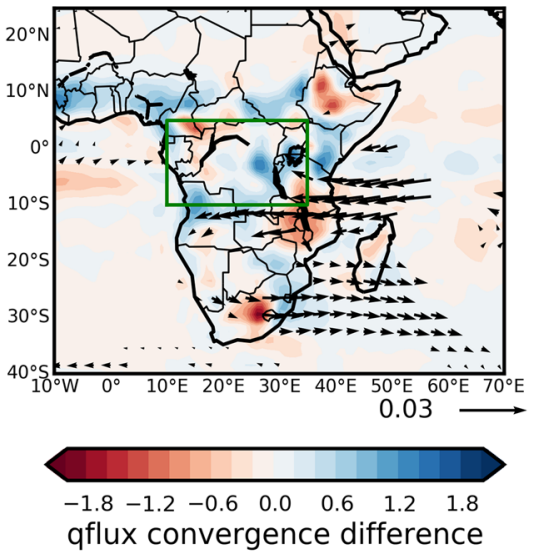

Fig. 11 As in Fig. 10 but for $700 \mathrm{hPa}$

In terms of the origin of the qflux, there are also differences between the composites. Models in the wettest composite experience an increase in the north-easterly and westerly fluxes into the basin in the future. They also feature anomalous easterlies at the south-eastern edge of the domain, which are the result of strengthened easterlies and weakened southerlies over the WIO and Mozambique Channel, respectively. In contrast, while models in the driest composite also show some enhanced north-easterly flow, this is less intense and less penetrating than the wettest models (Fig. 10g). In addition, there is some evidence of these models featuring enhanced westerlies over the equatorial WIO, potentially diverting moisture away from the Congo Basin.
Models in the driest composite also feature enhanced westerlies from the Atlantic, as in the wettest composite; however, these are associated with divergence which penetrates much further into the basin than in the wettest models. This again suggests that moisture is increasingly diverted from the core region of rainfall in the models with the driest changes.

Figure 10 also suggests that there are some wider differences between the composites in the way the WIO circulation field changes in the future. In the driest composite, the changes largely reflect a strengthening of the present-day pattern of north-easterlies in the north WIO, and westerlies in the central/south WIO. However, in the wettest composites, the strengthening of the present-day pattern is only 

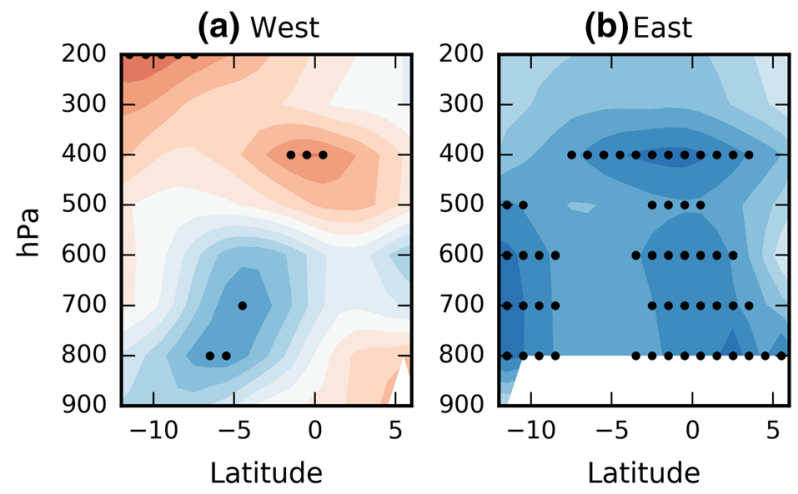

Fig. 12 Latitude/height and longitude/height cross-sections showing the correlation (r-values) across CMIP5 models between long term mean $\Delta P$ over the Congo Basin and long term mean $\Delta q f l u x$ across

evident in the north WIO north-easterlies. In the central/ south WIO there is significantly stronger easterly flow around $10^{\circ} \mathrm{S}$ which partially replaces or opposes westerly flow at $10 \mathrm{~S}$ and to the north. This does not map on to the present-day pattern of flux. This suggests that in the wettest composite there is a spatial shift in the WIO dynamical circulation, whereas in the driest composite there is simply a strengthening of the current pattern.

\subsection{Moisture flux at $700 \mathrm{hPa}$}

The moisture flux field at $700 \mathrm{hPa}$ is dominated by easterly winds, particularly in the north of the Congo Basin domain. As at $850 \mathrm{hPa}$, the patterns of $q f l u x$ and $q f l u x$ convergence at $700 \mathrm{hPa}$ are similar in both composites in the historical period (Fig. 11b, e). Convergence is strongly zonally banded, with convergence to the south of $\sim 2^{\circ} \mathrm{N}$, and divergence to the north. This pattern is similar in the future but with changes in intensity. In the wettest composite, convergence increases over the majority of the domain, while divergence intensifies at the northern boundary. There is also evidence of a northward shift in the boundary between convergence and divergence, as Fig. 11c shows anomalous convergence between $\sim 2^{\circ} \mathrm{N}$ and $5^{\circ} \mathrm{N}$. The driest composite shows an intensification of both convergence and divergence, though weaker than in the wettest composite.

There are some stark differences between $700 \mathrm{hPa}$ $\Delta q f l u x$ in the two composites. In the wettest composite, models feature enhanced north easterlies across the northern and north eastern boundary of the domain, and enhanced easterlies at the southern boundary. In the driest composite, models also feature enhanced north easterlies, but they are much more meridionally oriented, and south of the equator deflect eastward, diverting moisture out of the basin. This leads to anomalous westerlies across the south of the domain and into the Indian Ocean which is (c) North

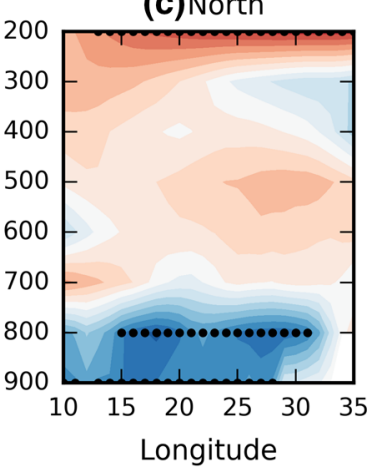

the: a western; b eastern; c northern; and d southern boundaries of the Congo Basin. Stipples indicate vertical grid locations which feature significant correlations at the $95 \%$ level

not a robust signal in the wettest models. In the region to the south east of the domain, the two composites show zonal winds of opposite direction. As at $850 \mathrm{hPa}$, there is a significant positive relationship between $\Delta q \operatorname{con} v$ and $\Delta P$ across all models $(\mathrm{r}=0.67, \mathrm{p}=0.0016)$.

\subsection{Flux across domain boundaries}

Figures $10 \mathrm{~g}$ and $11 \mathrm{~g}$ highlight regions where the $\Delta q f$ lux and $\Delta q$ conv signals in the two composites differ most significantly, and show that fluxes across the boundaries of the domain are often significant differentiators between models with the wettest and driest changes. Figure 12 shows the relationship (r-value) between model $\Delta q f l u x$ and $\Delta P$ across the suite of models at each boundary to the Congo Basin, throughout the atmospheric column. It confirms that $\Delta q f l u x$ from the north and east is positively and significantly correlated with $\Delta P$ over the basin; it also shows that the relationship between $\Delta q f l u x$ from the east and $\Delta P$ extends up to $400 \mathrm{hPa}$, whilst the northerly relationship is only significant at low levels. Figure 12a also shows that while enhanced westerly qflux from the Atlantic is quite prominent in the composite maps, it is only significant across the whole suite of models over a small number of gridboxes. Finally, there is evidence that enhanced qfux into the basin at low levels is related to enhanced flux out of the basin at upper levels, as seen across the western, northern and southern boundaries.

\section{Discussion and summary}

Previous research has indicated that mean rainfall amounts in the Congo Basin are unlikely to change significantly by the end of the twenty-first century, based on analysis of ensembles of coupled models (Haensler et al. 2013; Aloysius et al. 2016). This may be the case when considering large 
ensembles of equally-weighted members, but such a conclusion masks the complex spectrum of rainfall changes in this region, across different seasons and different models. In this paper we have focused on the DJF dry season and show that the amount of wetting projected in models is related to the strength of the enhancement of the low-level qfux circulation, and the increased amount of moisture entering the basin.

\subsection{Changes in rainfall magnitude and distribution}

The most consistent pattern to emerge across models is a slight wetting in the future, concurring with Aloysius et al. (2016) findings in CMIP5. In 10 months out of 12 median rainfall in the ensemble increases, and in 7 months, the whole spectrum of model values shifts positively. However, in 5 months, the spread of rainfall values increases in the future, with more models featuring drying. Even where seemingly robust changes occur in rainfall magnitude, such as in DJF where models generally agree on wetting across the domain, these changes are small compared to the range of climatological mean values of rainfall in individual models. For example, on average, in January the mean monthly $\Delta P\left(14.8 \mathrm{~mm} \mathrm{month}^{-1}\right)$ is only $15.8 \%$ of the median historical rainfall mean $\left(94.0 \mathrm{~mm} \mathrm{month}^{-1}\right)$. In addition, values of $\Delta P$ are small compared to the large range of model climatological values; in January, for example, the mean historical rainfall in models ranges from $28.1 \mathrm{~mm}$ to $165.0 \mathrm{~mm} \mathrm{month}^{-1}$, whereas the $\Delta P$ values only range from -4.0 to $43.5 \mathrm{~mm} \mathrm{month}{ }^{-1}$. Nevertheless, between October and May the means of the historical and future distributions in Fig. 1 are significantly different at the 95\% threshold, indicating that mean wetting across the basin is robust across the model spectrum.

Spatially, the distribution of rainfall in the future period is similar to that in the historical period, so the location of rainfall maxima in the historical period tends to persist into the future for all seasons. However, this does not necessarily translate into a spatial wet-gets-wetter pattern over the domain. Inspection of individual model historical rainfall (not shown) and $\Delta P$ (Fig. 5) shows that increases in rainfall do not necessarily map onto already-wet regions, and correlation analysis confirms that across models, there are only small areas which exhibit a significant positive relationship between $\mathrm{P}$ and $\Delta P$.

\subsection{Circulation changes associated with rainfall change}

Model rainfall changes under warming in the Congo Basin are more complex than a simple wet-get-wetter response, and there is disagreement amongst models in both the magnitude and spatial pattern of rainfall changes. Previous work on mechanisms of tropical rainfall change (e.g., Chadwick et al. 2013; Kent et al. 2015; Lazenby et al. 2018) suggests that intermodel uncertainty derives predominantly from uncertainty in the dynamical response to warming. Such a dynamical response can include changes in both vertical and horizontal motion.

Models with the wettest and driest changes exhibit pronounced differences in the structure of vertical motion, both in the meridional mean over the Congo Basin longitudes and the zonal mean near about the equator. Wettest models feature increases in uplift over the core of the continent, and decreases over areas including the northern subtropics and the Maritime Continent. Conversely, models which feature limited wetting on average exhibit less uplift over the continent, and comparatively weaker changes elsewhere. This helps explain the large differences in rainfall between the two composites. It is also indicative of wider changes in the tropical circulation alongside changes in the Congo Basin. Figure 9 indicates that models with the wettest change over the Congo Basin experience may also experience drying over the Maritime continent and wetting over East Africa, indicative of a weakening of the Walker circulation and switch to a more positive IODlike state, which has previously been identified as a possible response to warming in CMIP3 and CMIP5 models (Vecchi and Soden 2007; Shongwe et al. 2011; DiNezio et al. 2013). However, the wetting response across models is at odds with evidence of a drying trend over the Congo Basin in recent decades (Sanga-Ngoie and Fukuyama 1996; Laraque et al. 2001; Malhi and Wright 2004), which recent studies have linked to an enhancement of the tropical Walker circulation (Hua et al. 2016, 2018). Further work is needed therefore to establish the plausibility of simulated changes to zonal circulation and, by extension, Congo Basin rainfall.

Changes in the patterns of vertical motion in the composites will also be associated with changes in the horizontal circulation, as patterns of wind and convergence respond and provide feedbacks to enhanced uplift and subsidence. In DJF, there are some obvious differences in the qflux and qflux convergence fields between the models with the wettest and driest changes, with the wettest composite featuring a much greater enhancement of key fluxes at both $850 \mathrm{hPa}$ and $700 \mathrm{hPa}$, as well as spatial shifts in the pattern of the circulation over the west Indian Ocean. There is also a significant positive correlation between increased wetting and enhanced $q f u x$ from the north and east of the Congo Basin across the suite of models, indicating that increases in moisture advection and its convergence over the basin contribute to enhanced wetting.

Increases in qflux convergence (qconv) are also found to correlate significantly with increases in rainfall, just as high qflux convergence is correlated with model rainfall in the historical period (Creese and Washington 2016). As qflux convergence combines both wind and moisture components, it is possible that one of these is more dominant in explaining 
model differences in rainfall. If the wind component is dominant, this suggests that changes in the circulation may dominate rainfall change; if the $q$ component dominates, it could indicate either in situ (i.e. thermodynamic) increases in $q$, or greater $q$ transported into the basin (dynamical), or a combination of both. To help quantify the influence of the $q$ and wind components of qflux convergence, we have performed some simple calculations, whereby mean q from the driest models $\left(q_{\mathrm{D}}\right)$ is swapped with mean q from the wettest models $\left(\mathrm{q}_{\mathrm{W}}\right)$ in the calculation of $q c o n v$, and vice versa, such that:

$\Delta q_{\mathrm{W}} \operatorname{con} v=\Delta\left(\mathrm{d} q_{\mathrm{W}} u_{\mathrm{D}} / \mathrm{dx}+\mathrm{d} q_{\mathrm{W}} v_{\mathrm{D}} / \mathrm{dy}\right)$

and:

$\Delta q_{\mathrm{D}} \operatorname{con} v=\Delta\left(\mathrm{d} q_{\mathrm{D}} u_{\mathrm{W}} / \mathrm{dx}+\mathrm{d} q_{\mathrm{D}} v_{\mathrm{W}} / \mathrm{dy}\right)$.

This gives an indication as to whether changes in winds $(\Delta u, \Delta v)$ or changes in $q(\Delta q)$ play a greater role in rainfall differences between the two composites. These results are shown in Table 2. As described above, at $850 \mathrm{hPa}$ models in the wettest composite feature an increase in qflux convergence while those in the driest feature a decrease. When $q_{\mathrm{D}}$ is paired with winds from the wettest composite, there is still an increase in qflux convergence, though of weaker magnitude. However, when $q_{\mathrm{W}}$ is paired with winds from the driest models, the percentage decrease in qflux convergence is similar to the decrease when $q_{\mathrm{D}}$ is used. This suggests that in the wettest composite, changes both $q$ and wind are important, whereas in the driest, changes in the winds dominate the change in qconv. This is supported by analysis of the circulation fields of the swapped values at the eastern boundary of the basin (Online Resource 1, Figure S1). In the wettest composite, $850 \mathrm{hPa}$ and $700 \mathrm{hPa}$ circulation changes include an enhanced flux into the basin, meaning that changes in $q$ can influence moisture availability in the basin (Online Resource 1, Figures S1 and S2). However, in the driest composite there is outflow over much of the eastern boundary, meaning that differences in $q$ are less important, as the moisture is being diverted away from the basin regardless of its magnitude.

This analysis suggests that both the moisture and wind component of qflux convergence are important for understanding the different model responses to warming. This ties in with previous work which has found that qflux convergence exhibits stronger correlations with historical rainfall across models than wind convergence or $q$ alone (Creese and Washington 2016). Studies of both models and observations have identified qflux and qfux convergence as key factors differentiation between wet and dry models (Creese and Washington 2016, 2018), and wet and dry years (Pokam et al. 2012, 2014), as well as their role as branches of local overturning cells (Cook and Vizy 2015). In DJF, low-level qflux across the north and east boundaries of the Congo Basin, embedded within the reversed Asian monsoon flow, has been strongly related to model wetness within the basin, with higher r-values than in any other season (Creese and Washington 2016). These boundaries are also found to be important in the future; models which get wetter during DJF in the Congo Basin exhibit greater low-level qfux from the north, and low-tomid-level qflux from the east.

Changes in $q f u x$ and $q f u x$ convergence could be related to both thermodynamic and dynamic mechanisms of rainfall change. Enhanced winds could be related to a 'rich-getricher' dynamical feedback on increased $q$ under warming, where reduced gross moist stability in wet regions drives uplift and greater convergence at low levels (e.g. Chou et al. 2009). They could also be a consequence of a dynamical shift in the locations of convection under warming, which in turn influence patterns of low-level circulation. While increased $q$ could be purely a result of "in situ" thermodynamic increases in moisture under warming, it may also be exacerbated by strengthened wind convergence, or an increase in the advection of $q$ elsewhere.

It is not possible to disentangle the precise influence of each component across a suite of models without dedicated experiments; however, there is some evidence supporting the latter hypothesis (enhanced $q$ transported into the basin from elsewhere) as playing some role in intermodel differences in rainfall changes. First, as Fig. 12 shows, the wettest composite features enhanced qflux from the north and east, and the analysis above of swapped values shows enhanced winds and $q$ are important. As Fig. 7 shows, models which wet most over the Congo Basin also tend to get relatively wetter over the WIO at the East African coast. Analysis of SSTs between the composites (Fig. 13) shows that SST warming is much higher in this region in the wettest composite than the driest composite. Under a warmest-gets-wetter mechanism of rainfall change (Xie et al. 2010) we might expect this warming to drive enhanced evaporation, and thus enhanced $q$, over the WIO at the East African coast (Online Resource 1, Figure S3). This would provide a greater moisture source
Table 2 Calculations of qflux convergence $\left(10^{-8} \mathrm{~kg} \mathrm{~kg}^{-1} \mathrm{~s}^{-1}\right)$ using different combinations of mean $\mathrm{q}$ and mean winds from the driest and wettest composites

\begin{tabular}{llllll}
\hline & $\Delta($ qconv $), 850 \mathrm{hPa}$ & & & $\Delta($ qconv $), 700 \mathrm{hPa}$ & \\
\cline { 2 - 3 } \cline { 5 - 6 } & Wettest winds & Driest winds & & Wettest winds & Driest winds \\
\hline$q_{\mathrm{W}}$ & $0.466419(127.05 \%)$ & $-0.123061(-24.35 \%)$ & & $0.373057(317.14 \%)$ & $0.277326(80.28 \%)$ \\
$q_{\mathrm{D}}$ & $0.371642(74.27 \%)$ & $-0.192186(-23.54 \%)$ & & $0.274558(115.67 \%)$ & $0.195421(48.14 \%)$ \\
\hline
\end{tabular}


(a) Wettest $\triangle S S T$

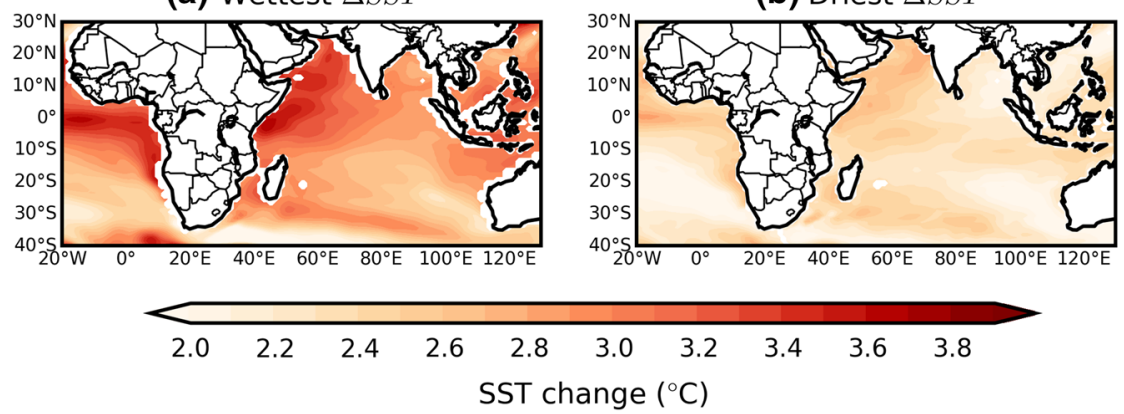

(c) Wettest $\triangle S S T$ minus Driest $\triangle S S T$

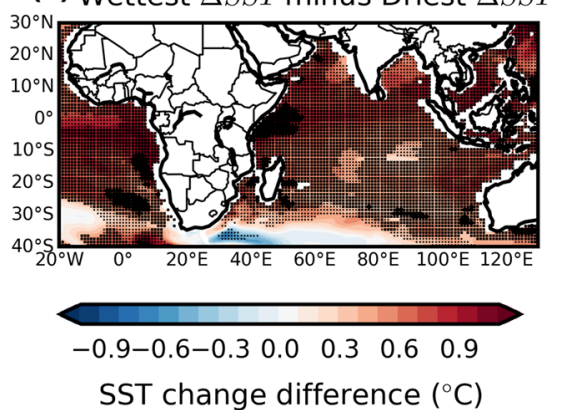

Fig. 13 Future minus historical SST ( $\Delta$ SST) in a wettest composite, b driest composite; $\mathbf{c}$ wettest composite $\Delta$ SST minus driest composite $\Delta$ SST. RCP8.5 data for FGOALs is missing, so driest composite includes only three models. Stipples in $\mathbf{c}$ occur at gridboxes where: (1) all wettest composite values are larger or smaller than all driest

for the easterly winds crossing into the Congo Basin in the wettest models.

The next steps in this research are to elucidate which magnitude and pattern of rainfall change is most plausible in this region. This will involve establishing whether the processes by which models produce future change are plausible processes in this region. Given that the observed drying trend in recent years has been linked to changes in the zonal circulation (Hua et al. 2016), an assessment of the ability of models to capture the processes associated with historical dry periods, similar to the analysis by James et al. (2015), may prove fruitful. The authors plan to explore this further in future work.

\subsection{Summary}

Our key findings are as follows:

1. There is a general trend towards wetting in the CMIP5 models across the annual cycle, and between October and May the increase in mean rainfall is significant between the future and present simulations at the $95 \%$ level.

2. In the models' future simulations there is general agreement that the rain band does not traverse as far south during SON and DJF, instead remaining in the southern half of the Congo Basin for longer than in the historical period.

3. In DJF, models tend to show wetting across the basin, but this ranges in magnitude from $2.3 \mathrm{~mm}$ season $^{-1}$ in the model with the smallest change, to $160.4 \mathrm{~mm}$ season $^{-1}$ in the model with the largest change; a difference of $158.1 \mathrm{~mm} \mathrm{season}^{-1}$. composite values (large dots); (2) all wettest composite values are greater or smaller than the driest composite mean (squares); (3) driest composite values are greater or smaller than the wettest composite mean (crosses); and (4) both (2) and (3) are true (small dots)

4. High magnitude wetting is associated with an enhancement of convection in the core convective region, while models with little rainfall change show a slight decrease in convection. This is linked to a poleward expansion of the Hadley cell in wetting models, and a weakened Indian Ocean Walker cell, which has been identified across CMIP3 and CMIP5 models but is at odds with recent trends over the Congo Basin.

5. Models with the wettest change feature an enhanced lowlevel circulation in the future, with greater qflux convergence and qflux from the north and east.

6. It is likely that the enhanced qflux and qflux convergence is a result of both increases in $q$ and a dynamical enhancement of low-level winds.

7. It is also likely that the warming West Indian Ocean acts as a greater source of $q$ for the basin in the future in the wettest models.

Acknowledgements The GCM data used in this study was made available through the Earth System Grid Federation (ESGF) Peer-to-Peer system (https://pcmdi.llnl.gov/search/cmip5/). The first author is fully funded by the UK Natural Environment Research Council (NERC) via a Doctoral Training Programme (Grant number: NE/L002612/1), and partly funded by a UK Met Office CASE studentship. Richard Washington is partly supported by NERC and the U.K. Government's Department for International Development (DfID) UMFULA project (NE/M020207/1). The authors acknowledge the helpful inputs of Callum Munday, Emma Howard, Wilfried Pokam, Rachel James and Neil Hart.

Open Access This article is distributed under the terms of the Creative Commons Attribution 4.0 International License (http://creativeco mmons.org/licenses/by/4.0/), which permits unrestricted use, distribution, and reproduction in any medium, provided you give appropriate credit to the original author(s) and the source, provide a link to the Creative Commons license, and indicate if changes were made. 


\section{References}

Akkermans T, Thiery W, Van Lipzig NPM (2014) The regional climate impact of a realistic future deforestation scenario in the congo basin. J Clim 27:2714-2734

Allan RP (2012) Regime dependent changes in global precipitation. Clim Dyn 39:827-840. https://doi.org/10.1007/s0038 2-011-1134-X

Allan RP, Soden BJ, John VO et al (2010) Current changes in tropical precipitation. Environ Res Lett 5:1-8. https://doi. org/10.1088/1748-9326/5/2/025205

Allen MR, Ingram WJ (2002) Constraints on future changes in climate and the hydrologic cycle. Nature. https://doi.org/10.1038/ nature 01092

Aloysius NR, Sheffield J, Wood EF (2016) Evaluation of historical and future simulations of precipitation and temperature in Central Africa from CMIP5 climate models. J Geophys Res Atmos 121:130-152. https://doi.org/10.1002/2015JD023656

Bala G, Caldeira K, Wickett $M$ et al (2007) Combined climate and carbon-cycle effects of large-scale deforestation. Proc Natl Acad Sci 104:6550-6555. https://doi.org/10.1073/pnas.0608998104

Balas N, Nicholson SE, Klotter D (2007) The relationship of rainfall variability in West Central Africa to sea-surface temperature fluctuation. Int J Climatol 27:1335-1349. https://doi. org/10.1002/joc

Bell JP, Tompkins AM, Bouka-biona $\mathrm{C}$ et al (2015) A processbased investigation into the impact of the Congo basin deforestation on surface climate. J Geophys Res Atmos. https://doi. org/10.1002/2014JD022586.Received

Black E, Slingo J, Sperber KR (2003) An Observational study of the relationship between excessively strong short rains in Coastal East Africa and Indian Ocean SST. Mon Weather Rev 131:74-94. https://doi.org/10.1175/1520-0493(2003)131\%3C0074:AOSOT $\mathrm{R} \% 3 \mathrm{E} 2.0 . \mathrm{CO} ; 2$

Brncic TM, Willis KJ, Harris DJ, Washington R (2007) Culture or climate? The relative influences of past processes on the composition of the lowland Congo rainforest. Philos Trans R Soc B Biol Sci 362:229-242. https://doi.org/10.1098/rstb.2006.1982

Chadwick R, Boutle I, Martin G (2013) Spatial patterns of precipitation change in CMIP5: why the rich do not get richer in the tropics. $\mathrm{J}$ Clim 26:3803-3822. https://doi.org/10.1175/JCLI-D-12-00543.1

Chou C, Neelin JD (2004) Mechanisms of global warming impacts on regional tropical precipitation*. J Clim 17:2688-2701. https ://doi.org/10.1175/1520-0442(2004)017\%3C2688:MOGWI O\%3E2.0.CO;2

Chou C, Neelin JD, Chen CA, Tu JY (2009) Evaluating the "rich-getricher" mechanism in tropical precipitation change under global warming. J Clim 22:1982-2005. https://doi.org/10.1175/2008J CLI2471.1

Cook KH, Vizy EK (2015) The Congo Basin walker circulation: dynamics and connections to precipitation. Clim Dyn 47:697-717. https://doi.org/10.1007/s00382-015-2864-y

Creese A, Washington R (2016) Using qflux to constrain modeled Congo Basin rainfall in the CMIP5 ensemble. J Geophys Res Atmos 121:13415-13442. https://doi.org/10.1002/2016JD025596

Creese A, Washington R (2018) A process-based assessment of CMIP5 rainfall in the Congo Basin: the September-November rainy season. J Clim 31:7417-7439. https://doi.org/10.1175/ JCLI-D-17-0818.1

Dezfuli A (2017) Climate of western and central equatorial Africa. Oxford Research Encyclopedia of Climate Science, pp 66. https ://doi.org/10.1093/acrefore/9780190228620.013.511

Dezfuli AK, Zaitchik BF, Gnanadesikan A (2015) Regional atmospheric circulation and rainfall variability in south equatorial Africa. J Clim 28:809-818. https://doi.org/10.1175/JCLID-14-00333.1
DiNezio PN, Vecchi GA, Clement AC (2013) Detectability of changes in the walker circulation in response to global warming. J Clim 26:4038-4048. https://doi.org/10.1175/JCLI-D-12-00531.1

Dong B, Gregory JM, Sutton RT (2009) Undestanding land-sea warming contrast in response to increasing greenhouse gases. Part I: transient adjustment. J Clim 22:3079-3097. https://doi. org/10.1175/2009JCLI2652.1

Durack PJ, Wijffels SE, Matear RJ (2012) Ocean salinities reveal strong global water cycle intensification during 1950 to 2000 . Science 336:455-458. https://doi.org/10.1126/science.1212222

Frierson DMW, Lu J, Chen G (2007) Width of the Hadley cell in simple and comprehensive general circulation models. Geophys Res Lett 34:1-5. https://doi.org/10.1029/2007GL031115

Giannini A, Lyon B, Seager R, Vigaud N (2018) Dynamical and thermodynamic elements of modeled climate change at the East African margin of convection. Geophys Res Lett. https://doi. org/10.1002/2017GL075486

Goddard L, Graham NE (1999) Importance of the Indian Ocean for simulating rainfall anomalies over eastern and southern Africa. J Geophys Res 104:19099. https://doi.org/10.1029/1999JD9003 26

Haensler A, Saeed F, Jacob D (2013) Assessing the robustness of projected precipitation changes over central Africa on the basis of a multitude of global and regional climate projections. Clim Change 121:349-363. https://doi.org/10.1007/s10584-013-0863-8

Hagedorn R, Doblas-Reyes FJ, Palmer TN (2005) The rationale behind the success of multimodel ensembles in seasonal forecasting- $\mathrm{I}$. Basic concept. Tellus A Dyn Meteorol Oceanogr 57:219-233. https://doi.org/10.1111/j.1600-0870.2005.00103.x

Hansen J, Sato M, Ruedy R (1997) Radiative forcing and climate response. J Geophys Res Atmos 102:6831-6864

Held IM, Soden B (2006) Robust responses of the hydrological cycle to global warming. J Clim 19:5686-5699. https://doi. org/10.1175/2010JCLI4045.1

$\mathrm{Hu}$ Y, Fu Q (2007) Observed poleward expansion of the Hadley circulation since 1979. Atmos Chem Phys 7:5229-5236. https://doi. org/10.5194/acp-7-5229-2007

Hua W, Zhou L, Chen H et al (2016) Possible causes of the Central Equatorial African long-term drought. Environ Res Lett. https:// doi.org/10.1088/1748-9326/11/12/124002 (accpeted)

Hua W, Zhou L, Chen H et al (2018) Understanding the Central Equatorial African long-term drought using AMIP-type simulations. Clim Dyn 50:1115-1128. https://doi.org/10.1007/s0038 2-017-3665-2

Huang Y, Chameides WL, Dickinson RE (2007) Direct and indirect effects of anthropogenic aerosols on regional precipitation over east Asia. J Geophys Res Atmos 112:1-17. https://doi. org/10.1029/2006JD007114

Huang P, Xie SP, Hu K et al (2013) Patterns of the seasonal response of tropical rainfall to global warming. Nat Geosci 6:357-361. https ://doi.org/10.1038/ngeo1792

Jackson B, Nicholson SE, Klotter D (2009) Mesoscale convective systems over western equatorial Africa and their relationship to large-scale circulation. Mon Weather Rev 137:1272-1294. https ://doi.org/10.1175/2008MWR2525.1

James R, Washington R, Rowell DP (2013) Implications of global warming for the climate of African rainforests. Philos Trans $\mathrm{R}$ Soc Lond B Biol Sci 368:20120298

James R, Washington R, Jones R (2015) Process-based assessment of an ensemble of climate projections for West Africa. J Geophys Res 120:1221-1238. https://doi.org/10.1002/2014JD022513

Johanson CM, Fu Q (2009) Hadley cell widening: model simulations versus observations. J Clim 22:2713-2725. https://doi. org/10.1175/2008JCLI2620.1 
Kent C, Chadwick R, Rowell DP (2015) Understanding uncertainties in future projections of seasonal tropical precipitation. J Clim. https ://doi.org/10.1175/JCLI-D-14-00613.1

Laraque A, Mahe G, Orange D, Marieu B (2001) Spatio-temporal variations in hydrological regimes within Central Africa during XXth Century. J Hydrol 245:104-117

Lazenby MJ, Todd MC, Chadwick R, Wang Y (2018) Future precipitation projections over central and southern Africa and the adjacent Indian Ocean: what causes the changes and the uncertainty? J Clim. https://doi.org/10.1175/JCLI-D-17-0311.1

Lewis SL, Lopez-Gonzalez G, Sonké B et al (2009) Increasing carbon storage in intact African tropical forests. Nature 457:1003-1006

Lohmann U, Feichter J (2004) Global indirect aerosol effects: a review. Atmos Chem Phys Discuss 4:7561-7614. https://doi. org/10.5194/acpd-4-7561-2004

Lu J, Vecchi GA, Reichler T (2007) Expansion of the Headley cell under global warming. Geophys Res Lett 34:L06805. https:// doi.org/10.1029/2006GL028443

Ma J, Xie SP, Kosaka Y (2012) Mechanisms for tropical tropospheric circulation change in response to global warming. J Clim 25:2979-2994. https://doi.org/10.1175/JCLI-D-11-00048.1

Malhi Y, Wright J (2004) Spatial patterns and recent trends in the climate of tropical rainforest regions. Philos Trans R Soc B Biol Sci 359:311-329. https://doi.org/10.1098/rstb.2003.1433

Malhi Y, Adu-bredu S et al (2013) African rainforests: past, present and future. Philos Trans R Soc Lond B Biol Sci. https://doi. org/10.1098/rstb.2012.0312

Maynard K, Royer JF (2004) Sensitivity of a general circulation model to land surface parameters in African tropical deforestation experiments. Clim Dyn 22:555-572. https://doi. org/10.1007/s00382-004-0398-9

Meehl GA, Stocker TF, Collins WD et al (2007) Global climate projections. In: Climate Change 2007 contribution of working group $\mathrm{i}$ to fourth assessment report of the intergovernmental panel on climate change, pp 747-846. https://doi. org/10.1080/07341510601092191

Ngomanda A, Jolly D, Bentaleb I et al (2007) Lowland rainforest response to hydrological changes during the last 1500 years in Gabon, Western Equatorial Africa. Quat Res 67:411-425. https ://doi.org/10.1016/j.yqres.2007.01.006

Nicholson SE (2017) The ITCZ and the seasonal cycle over equatorial Africa. Bull Am Meteorol Soc 30:337-348. https://doi. org/10.1175/BAMS-D-16-0287.1

Nicholson SE, Grist JP (2003) The seasonal evolution of the atmospheric circulation over West Africa and equatorial Africa. J Clim 16:1013-1030. https://doi.org/10.1175/15200442(2003)016\%3C1013:TSEOTA\%3E2.0.CO;2

Palmer TN, Doblas-Reyes FJ, Hagedorn R, Weisheimer A (2005) Probabilistic prediction of climate using multi-model ensembles: from basics to applications. Philos Trans R Soc B 360:1991-1998. https://doi.org/10.1098/rstb.2005.1750

Pokam WM, Tchotchou Djiotang LA, Mkankam FK (2012) Atmospheric water vapor transport and recycling in Equatorial Central Africa through NCEP/NCAR reanalysis data. Clim Dyn 38:1715-1729. https://doi.org/10.1007/s00382-011-1242-7
Pokam W, Bain CL, Chadwick RS et al (2014) Identification of processes driving low-level westerlies in west equatorial Africa. J Clim 27:4245-4262. https://doi.org/10.1175/JCLI-D-13-00490 .1

Pokam WM, Longandjo G-N, Moufouma-Okia W et al (2018) Consequences of $1.5^{\circ} \mathrm{C}$ and $2{ }^{\circ} \mathrm{C}$ global warming levels for temperature and precipitation changes over Central Africa. Environ Res Lett

Reichler T, Kim J (2008) How well do coupled models simulate today's climate? Bull Am Meteorol Soc 89:303-311. https://doi. org/10.1175/BAMS-89-3-303

Rowell DP (2012) Sources of uncertainty in future changes in local precipitation. Clim Dyn 39:1929-1950

Rowell DP, Chadwick R (2018) Causes of the uncertainty in projections of tropical terrestrial rainfall change: east Africa. J Clim. https://doi.org/10.1175/JCLI-D-17-0830.1

Saeed F, Haensler A, Weber T et al (2013) Representation of extreme precipitation events leading to opposite climate change signals over the Congo basin. Atmosphere (Basel) 4:254-271. https://doi. org/10.3390/atmos4030254

Sanga-Ngoie K, Fukuyama K (1996) Interannual and longterm climate variability over the Zaire river basin during the last 30 years. J Geophys Res 101:351-360

Shepherd TG (2014) Atmospheric circulation as a source of uncertainty in climate change projections. Nat Geosci 7:703-708. https://doi. org/10.1038/NGEO2253

Shongwe ME, van Oldenborgh GJ, van den Hurk B, van Aalst M (2011) Projected changes in mean and extreme precipitation in Africa under global warming. Part II: East Africa. J Clim 24:3718-3733. https://doi.org/10.1175/2010JCLI2883.1

Taylor KE, Stouffer RJ, Meehl GA (2012) An overview of CMIP5 and the experiment design. Bull Am Meteorol Soc 93:495-498. https ://doi.org/10.1175/BAMS-D-11-00094.1

van Vuuren DP, Edmonds J, Kainuma M et al (2011) The representative concentration pathways: an overview. Clim Change 109:5-31. https://doi.org/10.1007/s10584-011-0148-z

Vecchi GA, Soden BJ (2007) Global warming and the weakening of the tropical circulation. J Clim 20:4316-4340. https://doi. org/10.1175/JCLI4258.1

Washington R, James R, Pearce H et al (2013) Congo Basin rainfall climatology: can we believe the climate models? Philos Trans R Soc Lond B Biol Sci 368:20120296. https://doi.org/10.1098/ rstb.2012.0296

Werth D, Avissar R (2005) The local and global effects of African deforestration. Geophys Res Lett 32:1-4. https://doi. org/10.1029/2005GL022969

Xie SP, Deser C, Vecchi GA et al (2010) Global warming pattern formation: sea surface temperature and rainfall. J Clim 23:966-986. https://doi.org/10.1175/2009JCLI3329.1

Publisher's Note Springer Nature remains neutral with regard to jurisdictional claims in published maps and institutional affiliations. 